\title{
Ensuring daughter survival in Tamil Nadu, India*
}

\author{
Sharada Srinivasan \\ York University \\ 315 Founders College, 4700 Keele St; Toronto, ON M3J 1P3, Canada \\ Tel: +1 4167362100 Extn. 22739, Fax: +1 416736 5732, E-mail: sharada@york.u.ca.
}

Arjun S. Bedi

International Institute of Social Studies, Erasmus University Rotterdam

Kortenaerkade 12, 2518 AX, The Hague, The Netherlands

Tel: +31 70426 0493, Fax: +31 704260799 , E-mail: bedi@,iss.nl.

\begin{abstract}
The south Indian state of Tamil Nadu is a relatively recent addition to the list of Indian states to experience the phenomenon of 'missing girls'. Nonetheless, the government and NGOs in the state have been active for some time in collecting data to track gender differences in survival and in introducing interventions to prevent daughter elimination. Against this background, this article has two aims. First, it provides a temporal and spatial analysis of patterns of daughter deficits in Tamil Nadu over the period 1996 to 2003. Second, it undertakes an examination of the modus operandi, underlying assumptions, strengths and weaknesses of various interventions and assesses their effect on daughter elimination.
\end{abstract}

Key words: Declining sex ratios, daughter elimination, female infanticide, gender discrimination, interventions, Tamil Nadu, India, Asia

Oxford Development Studies (Forthcoming)

\footnotetext{
* We thank the Directorate of Public Health, Government of Tamil Nadu for data from the Vital Events Surveys, the Indian Council for Child Welfare, The Campaign against Sex Selective Abortion, Community Services Guild, Village Reconstruction and Development Programme, Poonthalir and Alternative for India Development, concerned government officials, health and nutrition workers at the state and district levels, and women's self-help groups in Salem for providing us with access to data and information, and for responding to our queries. We would also like to thank Pedro Goulart, Christophe Guilmoto, Michael Grimm, Stephan Klasen, Haroon Akram-Lodhi, participants at seminars and workshops in New Delhi, at the Institute of Social Studies, International Institute for Population Sciences, Mumbai and the University of Madras, as well as anonymous referees for their comments.
} 


\section{Introduction}

The phenomenon of 'missing women'1 is well-established in many Asian countries, including India. ${ }^{2}$ In India, while the 2001 census showed a slight increase in the overall population sex ratio, which rose from 927 females per 1000 males in 1991 to 933 in 2001, the proportion of girls to boys as captured by the sex ratio of those 0-6 has continued to decline, falling from 976 in 1961 to 927 in 2001. The sex ratio at birth has also declined sharply. Estimates based on the National Family Health Surveys (NFHS) and Sample Registration Surveys (SRS) indicate that this ratio has fallen from 943 in the 1980s to 876 in 2001-03. ${ }^{3}$ A substantial proportion of this anomaly may be attributed to the differential survival of girls and boys in the $0-6$ age group due to daughter elimination in the form of sex selection, infanticide and neglect (see Sen, 1990; Jha et al., 2006; Srinivasan and Bedi, 2008).

While several North Indian states have a long history of daughter elimination, it is a relatively recent phenomenon in the south Indian state of Tamil Nadu. Nevertheless, the state government and NGOs have been active in collecting data to track gender differences in survival and have pioneered programmes to prevent daughter elimination, some of which have been adopted by other states (Girl Child Protection Scheme) or have been considered for introduction on an allIndia basis (Cradle Baby Scheme). Programmes to prevent daughter elimination were first launched in Tamil Nadu in 1992 and after a first phase of interventions between 1992 and 1996, a second phase characterized by a sharp increase in intervention intensity was launched in May

\footnotetext{
${ }^{1}$ Sen (1990) first used the term 'missing women' to highlight low female to male sex ratios especially in India and China.

${ }^{2}$ Guilmoto (2009) provides a recent account of the problem in countries such as China and India which have a long history of declining sex ratios, and in countries such as Vietnam where it has just begun to emerge. According to Guilmoto, some of the Caucasian states have in recent years reported abnormal male birth rates. These include Azerbaijan, Georgia and Armenia and Albania in Eastern Europe.

${ }^{3}$ Sex ratio at birth figures for the 1980s are based on NFHS-1 and are from Retherford and Roy (2003). Figures for the period 2001-2003 are from the Office of the Registrar General (2007).
} 
2001. The interim period (May 1996 to May 2001) was marked by a lull in government efforts (see below for further details). ${ }^{4}$

In recent years, efforts to prevent daughter elimination in India have attracted high-profile attention. For instance, at a national meeting on "Save the Girl Child" on 28 April 2008, the Indian Prime Minister noted that, "No nation, no society, no community can hold its head high and claim to be part of the civilised world if it condones the practice of discriminating against one half of humanity represented by women". ${ }^{5}$ He went on to add that the various schemes undertaken by certain state governments, such as the "Dikri Bachao campaign of Gujarat, Girl Child Protection Scheme of Tamil Nadu, Devi Rupak Scheme of Haryana, Ladli campaign of Delhi and the scheme for cash incentives to panchayats ${ }^{6}$ for improving the village sex ratio of Punjab are good steps". Notwithstanding this endorsement, the nearly twenty year existence of such a programme in Tamil Nadu and the subsequent spread to other states, little is known about the nature and effectiveness of such schemes.

An exception is the work by Narayana (2008). In the context of an examination of country-wide patterns in gender differences in infant mortality, Narayana (2008) analyses the case of Tamil Nadu and suggests that policy interventions such as the Cradle Baby Scheme and social awareness campaigns have played an important role in reducing gender differences in infant mortality. Our article extends Narayana's exploratory analysis in several ways ${ }^{7}$ and has two aims.

\footnotetext{
${ }^{4}$ Changes in policy initiatives and measures to prevent daughter elimination track political developments in the state. The state government was headed by Ms. J. Jayalalitha of the AIADMK between June 1991 and May 1996. She lost the following elections, but returned to power in May 2001 and remained chief minister for most of the period between May 2001 and May 2006.

${ }^{5}$ http://pmindia.nic.in/lspeech.asp?id= 677 accessed on October 30, 2009.

${ }^{6}$ Panchayats are units of local self-government at the village level.

${ }^{7}$ Narayana (2008) relies only on the 1998 round of the Vital Events Survey (VES) and focuses on gender differences in infant mortality. In contrast, we use five editions of the VES data covering the birth years 1996 to 2003 to examine gender differences in both infant mortality and sex ratios at birth. The longer time period allows us to
} 
First, we examine patterns in daughter deficits in Tamil Nadu between 1996 and 2003. Following the pattern of interventions, we focus on changes before and after 2001. Second, we examine the rationale, strengths and weaknesses of interventions and provide an assessment of their effects on daughter elimination.

At the outset it is important to point out that we do not claim or attempt to provide an impact evaluation (or causal assessment) of the schemes. A number of schemes were introduced around the same time and throughout the state, which makes it difficult to isolate the effect of a particular scheme. Notwithstanding this caveat, given the lack of a full analysis of the workings of such schemes, their continued uptake by several states, and the importance of the issue under consideration, it is necessary to analyse the available information to assess whether such schemes can play - and may have played - a role in preventing daughter elimination. ${ }^{8}$

The article is based on primary and secondary data which are both quantitative and qualitative in nature. The main source of quantitative data is five rounds of Vital Events Surveys (VES) conducted by the Directorate of Public Health (DPH) of Tamil Nadu annually between 1998 and 2000 (for the birth years 1996, 1997, 1998 and 1999) and in 2004 (for the birth year 2003). Information on various interventions is obtained from relevant government departments, NGOs and newspaper reports. Interviews and discussions with NGO staff, government staff, women's

analyse temporal and spatial patterns in daughter deficit and in interventions. We also provide a more comprehensive discussion of the various interventions.

${ }^{8}$ Internationally, there are a few studies that have examined the effect of interventions on daughter deficit. See for instance, Li (2007) for China and Chung and Das Gupta (2007) for South Korea. Li (2007) suggests that China's "Care for Girls" campaign, which was implemented in 24 counties between 2000 and 2005 and scaled up countrywide in 2006, led to an improvement in the sex ratio at birth in these 24 counties. While the campaign contained several components, $\mathrm{Li}$ argues that punitive measures were most effective in the short run while in the long run advocacy programmes would help change people's preference for sons. Chung and Das Gupta note that in South Korea, the sex ratio at birth, while far from normal, may have been improving since the mid-1990s. They attribute this improvement to a decline in son preference emerging from broad development processes such as industrialization and urbanization. These have weakened traditional kinship and lineage systems, specifically related to male lineage, dependence on sons for old age support, inheritance and women's marginalization. Their findings are based on an analysis of fertility surveys conduced in 1991 and 2003, specifically looking at women's responses on the imperative to have a son. They conclude that public policies should aim to change societal norms and to accelerate the process of diffusion of new values to reverse the current trends in child sex ratios. 
self-help groups (SHG) and local respondents in different districts were carried out during several rounds of fieldwork between 2000 and 2008 .

To preview our results, based on the Vital Events Surveys (VES) we find that between 1996 and 2003 there has been a sharp decline in daughter deficit. Other sources of data such as the SRS and Primary Health Centre (PHC) records also support this finding. Furthermore, we find that the decline is especially sharp in those parts of the state where government and NGO interventions have been most active, suggesting that over the period under scrutiny the various interventions have led to a reduction in daughter elimination.

The rest of the article is organized as follows. To contextualize the article, the next section presents a background on the origin of and underlying reasons for daughter deficit in Tamil Nadu. Section 3 presents a temporal and spatial analysis of daughter deficit in the state. Section 4 provides an assessment of the various interventions that have been implemented in Tamil Nadu since official acknowledgement of the prevalence of female infanticide (FI) in the early 1990s. Section 5 provides a more detailed account of the experience of tackling female infanticide in Salem - the district with the highest daughter deficit in the state - to demonstrate the iterative and dynamic nature of policy making. Section 6 summarises and concludes.

\section{The origin of daughter deficits in Tamil Nadu}

Conventionally, much of the daughter shortfall in India has been accounted for by states such as Punjab, Haryana and Delhi in the north and Gujarat and Maharashtra in the west. An early essay on India's demography (Visaria, 1967) demonstrated that female to male sex ratios were persistently lower (i.e., more masculine) in the northern and western states, and higher in the southern and eastern states. More than a decade later, Sopher (1980: 296) commented that the 
"completeness of the regional dichotomy is impressive". Dyson and Moore (1983) and Miller (1989) confirmed this diagonal divide.

While daughter deficits are lower in Tamil Nadu as compared to other parts of India, analysis based on the 0-6 female to male sex ratio suggests that Tamil Nadu is not immune to the country-wide declining trend in this ratio, and that the diagonal divide is no longer valid (Srinivasan and Bedi, 2009). A comparison of the 0-6 sex ratio (based on the 1991 and 2001 censuses) across urban and rural areas provides a clear picture of the similarities and differences between Tamil Nadu and the rest of the country. Unlike the rest of the country where the urban 0-6 sex ratio is considerably lower than the rural 0-6 sex ratio (903 versus 934 in 2001), the pattern in Tamil Nadu is exactly the opposite (951 versus 931 in 2001). Between 1991 and 2001, the 0-6 sex ratio in urban India recorded a drop of 32 points (935 to 903). Over the same period there was a modest decline of four points (955 to 951) in urban Tamil Nadu. The considerably higher $0-6$ sex ratio and the smaller decline over the decade suggests that urban Tamil Nadu is different and does not closely track the trend prevailing in other parts of urban India. In marked contrast, the rural 0-6 sex ratio for Tamil Nadu is lower than the $0-6$ sex ratio for rural India. Additionally, between 1991 and 2001, the 16 point decline in the 0-6 sex ratio in rural Tamil Nadu is similar to the decline (14 points) in the $0-6$ sex ratio for rural India. ${ }^{9}$

There is a large literature on the reasons for daughter discrimination in India. The various explanations that have been advanced may be usefully divided into factors associated with son preference and those associated with daughter aversion. The reasons for son preference include, among others, the need for sons to carry the family name, to perform lifecycle rituals, social

\footnotetext{
${ }^{9}$ While it is not the purpose of this article to delve into reasons for the difference between urban and rural Tamil $\mathrm{Nadu}$ it is quite likely that there is a non-linear relationship between daughter deficit and urbanization/industrialization. Using an evolutionary perspective, in the case of Sweden, Johansson (1984) finds evidence for an increase in excess female mortality during the initial stages of agricultural modernization which is followed by a reduction as urbanization and industrialization spreads. Rural Tamil Nadu has also been experiencing agricultural modernization and as industrialization spreads across the state it may well be that the sex ratio patterns prevailing in urban Tamil Nadu also spread to the rural areas of the state.
} 
status and provision of financial support in old age. Given the prevalence of a virilocal marriage system $^{10}$, daughter aversion is driven by the notion that a daughter is an economic burden and once married will not contribute financially to the natal family. The investments in her upbringing and dowry are therefore viewed as a drain on her natal family (Miller, 1981; Basu, 1999; Croll, 2000).

While the factors contributing to son preference and daughter aversion are widespread, there are variations. Of relevance for this article, the diagonal divide in sex ratios noted in early demographic analyses has been attributed to the higher demand for female labour in rice cultivation, the staple cereal in South India as compared to wheat, the staple in the North (Bardhan, 1974; Bardhan, 1982) and more importantly to differences in kinship and marriage practices between the North and the South (Dyson and Moore, 1983). Traditionally, South Indian marriages have been geared towards strengthening existing kinship arrangements through marriage among blood relatives. Cross kin marriages ${ }^{11}$ based on the principle of exchange of daughters between equal-status families used to be common and dowry was symbolic. Given this marriage pattern, there was little difference between the natal and marital family. In contrast, North Indian marriages are directed towards creating new alliances and are expected to take place within the same caste but beyond any consanguinity. Dowry is the norm and postmarriage, geographical as well as emotional ties with the natal family tend to get attenuated.

However, since the 1960s in Tamil Nadu, "a weak level of son preference seems to have become converted into a strong non-preference for daughters" (Basu, 1999: 252). Several ethnographic studies in different parts of the state have argued that increased differences in income and wealth, within the same formerly equal-status kin groups, seem to have driven two important and

\footnotetext{
${ }^{10}$ A system in which a married couple lives with or near the husband's family.

${ }^{11}$ The range of marriageable kin among Brahmin and non-Brahmin caste groups extends beyond the cross-cousin and hence, as Kapadia (1995) suggests, it is appropriate to use the term cross-kin marriages.
} 
related changes in kinship arrangement - a shift from isogamous (equal status) kin endogamy to hypergamous (asymmetrical status) kin exogamy and the emergence and spread of the practice of dowry (see Vasanthi Devi, 1991; Heyer, 1992; Kapadia, 1993). From being an upper caste/class practice, dowry has become an all caste/class phenomenon, with large movements of wealth replacing the symbolic exchange of gifts (AIDWA, 2003; Srinivasan, 2005). In short, kinship and marriage practices in Tamil Nadu have acquired North Indian overtones and rather than strengthening existing kinship arrangements, marriages in the South have become a strategy for forging new alliances for upward mobility and accumulating wealth, with attendant negative consequences for daughters.

Within the state, daughter elimination first came to light in the form of female infanticide among specific castes in Madurai (Soundarapandian, 1985; Venkatramani, 1986; Jeeva et al., 1998) and Salem districts in the 1980s (Venkatachalam and Srinivasan, 1993). Based on a state-level analysis, Chunkath and Athreya (1997) provided evidence of the spread of the practice to eight districts and amongst 35 self-ascribed caste groups. More recently, Srinivasan and Bedi (2008) have shown that 15 of the state's 29 districts exhibit some form of daughter deficit.

While the subsequent spread of the practice to other castes and districts may be attributed to geographical and caste contiguity and the emergence of a socially acceptable norm, the reasons for the susceptibility and the willingness of dominant caste groups around Madurai and Salem to embrace new social arrangements and subsequently to engage in daughter elimination has been studied by Vasanthi Devi (1991) in Madurai and Srinivasan (2006) in Salem. Both authors argue that, in part, the emergence of the practice may be traced to the economic and social transformation brought about by canal irrigation and other measures undertaken during the green revolution in the 1950s and 1960s. Two arguments are advanced. First, increases in income and wealth generated through access to irrigated land contributed to reduced fertility. A 
reduction in fertility with no change in the underlying reasons for son preference increased the household's desire to ensure the birth of a son. Second, as described above, increases in income/wealth differentials driven by unequal access to irrigated land across kin groups led to changes in kinship arrangements and marriage practices, and the emergence of dowry, which in turn fuelled daughter aversion.

\section{Temporal and spatial patterns of daughter deficit in Tamil Nadu}

\subsection{Definitions and a framework}

We define daughter deficit as the gap between the expected number of daughters and the actual number of daughters born or alive in a certain age group. It is a proxy for the extent of daughter elimination and may occur before birth (pre-birth deficit), within a year after birth (early postbirth deficit) or beyond age one (late post-birth deficit). Pre-birth daughter deficits are associated with the use of ultrasound scans to determine the sex of the foetus followed by foeticide; early post-birth deficit is most likely to be an outcome of female infanticide, while late post-birth deficit may be attributed mainly to female neglect. In this article, we focus on deficits which occur before birth and within a year after birth. ${ }^{12}$

In order to estimate the extent of daughter deficit, the first task is to establish benchmarks for the number of daughters expected in the absence of interference against which the prevailing figures may be compared. While a detailed discussion is provided in Srinivasan and Bedi (2008), it is widely accepted that in the absence of interference, the sex ratio at birth is around 952 female live births per 1000 male live births. Sex ratios at birth (SRB) which are statistically different from and less than 952 are treated as evidence of pre-birth daughter deficit. Thus, pre-

\footnotetext{
12 Srinivasan and Bedi (2009) show that in Tamil Nadu for the period that we focus on, daughter deficit may be attributed almost entirely to pre- and early post-birth deficit (within the first year of birth).
} 
birth daughter deficit $\left(D D_{\text {pre }}\right)$ defined as the gap between the number of expected girls and the number of girls born may be calculated as,

$$
D D_{\text {pre }}=N_{m} S R B_{e}-N_{f},
$$

where, $N_{m}$ and $N_{f}$ denote the number of live male and female births respectively and $S R B_{e}$ denotes expected SRB.

Turning to post-birth deficit, for various biological reasons, female infant mortality is usually lower than male infant mortality. Several authors (see Waldron, 1983; Johansson and Nygren, 1991; Hill and Upchurch, 1995) have shown that in the absence of interference, female infant mortality lies in the range of about 77 to 85 percent of male infant mortality. Model life tables for the United States and the United Kingdom also show that the expected female infant mortality rate (IMR) lies at about $80-82$ percent of male IMR.${ }^{13}$ Based on these estimates, female IMR is expected to be about 80 percent of male IMR. Thus, post-birth daughter deficit $\left(D D_{\text {poss }}\right)$ is,

$$
D D_{\text {post }}=\left\{F I M R_{s}-\left(0.8 * M I M R_{s}\right)\right\} N_{f}
$$

where $F I M R_{s}$ and $M I M R_{s}$ are estimated female and male infant mortality rates respectively.

Alternatively, (2) may be written as,

$$
D D_{\text {post }}=\left(F I M R_{s}-F I M R_{e}\right) N_{f},
$$

where $F I M R_{e}$ denotes the expected female IMR. If estimated female IMR is higher and statistically significantly different from the expected female IMR, it is treated as evidence of postbirth daughter deficit.

\footnotetext{
${ }^{13}$ For the United Kingdom, model life tables are available at http://www.statistics.gov.uk/downloads/theme population/Interim Life/ILTUK0507Reg.xls and for the United States model life tables are available at http://www.cdc.gov/nchs/products/life tables.htm. Accessed on June 12, 2009 .
} 
Combining (1) and (3), total daughter deficit (TD) in a given year/period ( $t$ ) may be written as,

$$
\begin{gathered}
T D_{t}=N_{m t} S R B_{e}-N_{f t}+\left(F I M R_{s t}-F I M R_{e t}\right) N_{f t} \\
D D_{p r e, t}
\end{gathered} \quad D D_{p o s t, t} .
$$

To compute (4), as will be discussed below, we use information on the total number of live female births $\left(N_{f f}\right)$ from the census conducted in 2001, while Vital Events Surveys covering the period 1996-1999 and 2003 are used to obtain estimates of SRB and IMR for the periods before and after 2001, respectively. Based on (4), changes in total deficit between 1996-1999 and 2003 $\left(T D_{t}-T D_{j}\right)$ may be decomposed into changes in $S R B$ and changes in differential (male-female) infant mortality between 1996-1999 and 2003. Here, the implicit assumption is that it is unlikely that there has been a sharp change in fertility during the period under scrutiny $\left(N_{f t}=N_{f j}\right){ }^{14}$

\subsection{Data}

Following (4), at the very least, an intra-state assessment of daughter deficits requires districtlevel data on SRB and male and female infant mortality. Such an assessment should yield a more detailed idea of daughter deficit and its patterns which a state-level analysis may mask. The civil registration system, which in principle should contain district-level figures on vital events, is not complete. Other sources such, as the SRS, only provide information on SRB and infant mortality at the state level and do not support an intra-state examination. Census data on district-level SRB was only collected for the first time in 2001 and hence does not permit a temporal analysis and furthermore the census does not gather data on infant mortality.

\footnotetext{
14 While we do not have census information on the number of births for 1997-2000 and for 2003, the VES data show that the average number of births per year between 1997 and 2000 was 173,651 while in 2003 the number of births was 171,427 or a small reduction of 1.28 percent. According to the Sample Registration Survey (www.census.tn.nic.in accessed on December 10, 2007) in 1997, the birth rate (95\% C.I.), that is, the number of live births per 1000 population, was 19 (18.4-19.6) per 1000 for the state and 19.3 (18.6-20) and 18.3 (17.1-19.5) in rural and urban areas, respectively. In 2003, the birth rates (95\% C.I.) were 18.3 (17.8-18.8), 18.8 (18.2-19.4) and 17.3 (16.2-18.4) for the state, rural and urban areas, respectively. These figures show that between 1997 and 2003 the births rates in rural and urban areas are not statistically different at a significance level of 5 percent.
} 
Accordingly, while we do use SRS and Census 2001 data, the bulk of the article relies on five rounds of Vital Events Surveys (VES) conducted by the Directorate of Public Health of Tamil Nadu. These VES were launched by the state government in 1997 to track vital events on a more regular basis and to generate district-level information for the purpose, among others, of reducing infant mortality, infanticide and the gender gap in IMR. Since then, several rounds of the VES have been conducted spanning the birth years 1996, 1997, 1998, 1999 and 2003. These surveys gather information on, among other things, the number of male and female live births, and infant deaths during the year preceding the survey. Each of the surveys is based on a sample of about six million individuals in rural (non-municipal) areas and three million individuals in urban (municipalities and corporations) areas. At the district level this entails a sample size of about 200,000 individuals in rural (non-municipal) areas and 100,000 individuals in municipal areas. The surveys are conducted by 36 trained enumerators per district. While additional details on the surveys are available in Athreya (1999), the methodical approach to data collection and data capture and the large size of the sample suggest that the surveys contain high-quality data on vital events. The volume of data available in each of the VES, nine million individuals and 174,000 births, may be contrasted with the Sample Registration Surveys, which usually cover 355,000 individuals and about 6,000-7,000 births in each round.

To analyse temporal patterns we divide the period covered by the data into a pre- and post- 2001 period. This division coincides with a time period before and after intensification of efforts to tackle daughter elimination. To focus on these two broad periods, pre-2001 estimates are based on VES covering the period 1996 to 1999. Information from the four surveys is pooled and accordingly, the pre-2001 analysis relies on responses from 36 million individuals or about 1.25 million individuals per district. The total number of births analyzed during this period is 694,605 . For the post-2001 analysis we rely on VES 2003 which covers nine million individuals and 
includes 171,427 births. In addition, we use data from the census conducted in 2001, which covers 14 million households and 895,765 births for Tamil Nadu.

\subsection{Estimates}

Infant mortality and post-birth deficit, Tamil Nadu, 1996-2003

Table 1 provides VES-based estimates of IMR for the whole state over the period 1996-1999 and for 2003. As shown in the table, in 1996-1999 the male IMR was 36 while the female IMR was 39, compared to an expected female IMR of 29. In terms of a broad spatial distribution, the female disadvantage emanates mainly from rural areas. In the urban areas of the state the estimated and expected female IMR (19 versus 18.4, respectively) are not statistically different. The rural areas of the state reveal a different picture with a male IMR of 41 and a female IMR of 48, compared to an expected female IMR of 33.

A few years later, based on VES 2003, the male and female IMR are the same (30 per 1000). While these numbers still reflect a statistically significant 5.7 point female disadvantage, temporally, the decline in female IMR outstrips the decline in male IMR, resulting in a 4.5 point reduction in the gap between estimated and expected female IMR. The reduction is pronounced in rural areas with a sharp 8.2 point narrowing in the gap between estimated and expected female IMR (a reduction from 15.2 to 7). In contrast, in urban areas the temporal change between estimated and expected female IMR is a statistically significant widening of the gap and suggests an increase in daughter deficit. However, the magnitude of the gap is not large.

Table 2 provides a district-specific picture of male and female infant mortality for 1996-1999 and 2003. Since differences in infant mortality in Tamil Nadu are essentially a rural phenomenon, we 
provide details only for rural areas of the state. ${ }^{15}$ In 1996-99, the estimated female IMR in rural areas of 19 of the state's 29 districts was (statistically) greater than the expected female IMR. While a deficit exists in many districts, districts with the strongest evidence of post-birth female deficit are rural Salem and rural Dharmapuri where the gap between estimated and expected female IMR is 82 and 66 points, respectively. These two districts are followed by rural parts of Theni (43 points), Namakkal (25.6) and Madurai (25.2).

District-specific figures for 2003 show a clear decline in the number of districts with evidence of daughter deficit (Table 2). Post-birth daughter deficit is now restricted to 10 districts as compared to 19 districts in 1996-1999. While both districts with the largest female disadvantage in 1996-1999 continue to display evidence of post-birth deficit in 2003, there is a sharp decline in the extent of the deficit. Across the various districts, rural Salem and Dharmapuri experience the sharpest decline in the gap between estimated and expected female IMR. The gap drops from 82 to 17 in Salem and from 66 to 13 in Dharmapuri respectively. These two districts no longer have the highest differential between estimated and expected female IMR and are replaced by rural parts of Dindigul and Tiruchirapalli. While the decline in Salem and Dharmapuri has been accompanied by an increase in deficit in other districts, the overall message is one of declining post-birth daughter deficit (see also Narayana, 2008).

To obtain an idea of the absolute magnitude of this deficit we use (4) and the estimated and expected female IMR for 1996-1999 and 2003 to compute deficits for both periods and subsequently compute changes in post-birth deficit over time. As shown in Table 2, Column 5,

\footnotetext{
15 Average male (female) infant mortality in urban areas in 1996-99 is 23 (19) with a small standard deviation of about 5 (6) and ranges from 13 (9) to 35 (34) across districts. In 2003 the numbers are virtually unchanged with a male (female) infant mortality rate of 24 (21) a standard deviation of 6 (7) and ranges from 13 (9) to 38 (35).
} 
we estimate an annual post-birth deficit of about 4,500 girls for the period 1996-1999. ${ }^{16}$ In terms of a district-specific distribution, for the period 1996-1999 a little more than 50 percent of the deficit may be attributed to just two districts - Dharmapuri accounts for 26.5 percent of the deficit while Salem accounts for 24 percent of the deficit.

Post-birth deficit figures for 2003 are presented in Column 6 of Table 2. As shown, post-birth deficit records a decline of about 2,700 girls, which translates into a decline of about 60 percent between the two reference periods. The decline is dominated by Dharmapuri and Salem which together account for 85 percent of the decline. Post-birth daughter deficit in Dharmapuri declined from 1,189 to 219 , or a reduction of about 82 percent, while the corresponding decline in Salem is 73 percent (from 1,067 to 283). Other districts which displayed strong evidence of post-birth daughter deficit in 1996-1999 present a mixed picture and there are four districts in which the deficit is statistically different and larger than in 1996-1999. However, these increases are modest. The main picture emerging from the analysis is that post-birth daughter deficit experienced a spectacular decline between 1996-1999 and 2003 and that most of the decline may be attributed to just two districts - Salem and Dharmapuri.

Evidence in support of the decline in post-birth daughter deficit also comes from other sources. Over roughly the same period, while levels differ, SRS-based estimates present temporal patterns that are remarkably similar. According to SRS data, in 1999, the gap between estimated and expected female IMR was 14 points while in 2003 the gap declined to 5.8 points. ${ }^{17}$ Both sources

\footnotetext{
16 Based on records maintained by primary health care centers in the state, for the birth year 1995, Chunkath and Athreya (1997) report 3,226 cases of female infant deaths due to 'social causes', a euphemism for infanticide. The authors write that PHC records may not be complete but that they provide useful information to support districtlevel comparisons.

17 According to SRS data, (SRS Bulletin, Volume 35, No. 1) the female IMR in Tamil Nadu in 1999 was 54.5 while male IMR was 50.3 , that is a gap of 14.26 points $(54.5-50.3 * 0.8)$ between expected and actual female IMR. In 2003, (SRS Bulletin, Volume 39, No. 1) female IMR was 41 per 1000 and male IMR was 44 per 1000, a gap of 5.8 points (41-44*0.8).
} 
of data reveal that during this period post-birth daughter deficit dropped sharply and may have halved between 1996-1999 and 2003. ${ }^{18}$

SRB and pre-birth daughter deficits, Tamil Nadu, 1996-2003

Computations covering the period 1996-1999 yield a SRB of 935 for the state, and 943 and 932 for the urban and rural parts of the state respectively (Table 3). While the urban SRB of 943 lies just about within the expected range (a 95 confidence interval of 935 to 951), the rural SRB of 932 and the SRB for the state as a whole (935) are statistically different from 952, suggesting a pre-birth daughter deficit. Census information confirms this pattern-the state's SRB in 2001 remains at 935, indicating a possible pre-birth deficit. The lower than expected ratio is driven by the rural SRB (919) which is 33 points lower than expected. At 960, the SRB in urban areas does not suggest a pre-birth deficit.

Between 1996-1999 and 2003, for the state as a whole there is a nine point increase in the SRB from 935 to 944 (p-value 0.092). While both urban and rural Tamil Nadu experience an increase in the SRB, in neither case is the change statistically significant. In 2003, the SRB for urban Tamil Nadu is well within the normal range, while for the rural parts the data continue to show evidence of pre-birth daughter deficit. As with the IMR patterns, pre-birth daughter deficit arises mainly from rural areas of the state.

Table 3 provides district-specific information on SRB for 1996-1999 and 2003. As shown in Column 1 of the table, based on the 1996-1999 VES data the SRB ranges from a low of 874 in the Northern district of Salem to a high of 965 in the southern district of Thuthukudi. Eleven of

\footnotetext{
18 A third data source, NFHS-3, conducted in 2005-06 does not yet provide state-level, gender-specific IMR. However, existing data show that for the five-year period preceding the survey, the IMR in Tamil Nadu was 30.4 (wnw.nffsindia.org/nfbs3_national_report), a figure which matches the IMR estimate of 30 obtained using VES 2003 (see Table 1). A fourth data source, state PHC records, also leads to the same conclusion. The number of female infant deaths due to "social causes" declined from an average of about 3,000 a year between 1995 and 1999 to 372 in 2002, that is, a decline of about 88 percent (State Planning Commission, 2005).
} 
the state's districts have SRB that are statistically different and lower than 952 at conventional levels of significance. Census-based figures for 2001 (Column 2) show that the SRB varies from a low of 838 in Salem to a high of 988 in the Nilgiris. According to the census, there are 18 districts where the SRB is less than 952 and 12 where it is less than or equal to 935 . A comparison of the VES and census-based figures suggest that the VES data are reliable in terms of identifying districts with unusually low SRB. ${ }^{19}$ There are clear differences across the rural and urban parts of the districts. In 1996-1999 except for two districts (870 in urban Karur and 880 in urban Virudhunagar) the urban parts of most other districts have SRB that are not statistically different from the expected SRB (Column 4). In contrast there is evidence of pre-birth deficit in the rural areas of 10 districts (Column 7).

To compute the absolute magnitude of pre-birth daughter deficit for 1996-1999 we rely on (1). Estimates of pre-birth daughter deficit are displayed in Table 4. Based on the gap between the expected and actual SRB in 1996-1999 and the total number of live births from Census 2001, we compute a pre-birth deficit of 6,244 females (Column 1). ${ }^{20}$ Most of this shortfall emanates from the rural areas of the state and is dominated by Salem (27 percent of the deficit) followed by Dharmapuri (12 percent). Between 1996-1999 and 2003 the shortfall declined slightly from 6,244 to 5,294 (6244-950). For the most part there is not much change in pre-birth daughter deficit in urban areas as 26 of the 29 districts do not show statistically significant differences in SRB between 1996-1999 and 2003 (not presented in table). In rural areas, pre-birth daughter deficit declined from 4,386 to about 3,318 (4386-1068) and five districts reveal a reduction in pre-birth

\footnotetext{
${ }^{19}$ Except for one district (Nagapattinam), the remaining 10 districts which have a SRB statistically lower than 952 in the VES also show up as districts with a shortfall in the census figures. Of the eight additional districts displaying shortfalls based on census figures, five also had ratios less than 952 in the VES but were not statistically different from the expected ratio.

20 This figure, which depends on survey based estimates of SRB and only on those districts where the gap between the estimated and expected SRB are statistically different, probably understates the extent of pre-birth daughter deficit. Based on census figures the extent of the pre-birth daughter deficit is closer to 10,000. We rely on the survey-based estimates as we are interested in temporal changes.
} 
daughter deficit that is statistically different from zero (Column 6). Between 1996-1999 and 2003 the SRB in rural Salem records a statistically significant increase from 843 to 893 translating into a reduction in pre-birth daughter deficit in the district. In Dharmapuri the differences in SRB are not statistically significant and the extent of pre-birth deficit remained unchanged. While the decline in pre-birth deficit is not as spectacular as the decline in post-birth deficit, the important point is that a reduction in post-birth deficit (female infanticide) is not accompanied by an increase in pre-birth deficit (sex selection).

\section{Preventing daughter elimination in Tamil Nadu}

In 1992, the government of Tamil Nadu officially acknowledged the prevalence of female infanticide and announced several schemes to 'eradicate' it. These included the Cradle Baby Scheme (CBS), legal action against perpetrators of infanticide and the Girl Child Protection Scheme (GCPS). In addition to these three government-led interventions, several NGO-led initiatives were located in the three districts of Madurai (including Theni), Salem (including Namakkal) and Dharmapuri. We examine each of these interventions.

\subsection{Cradle Baby Scheme (CBS)}

The Cradle Baby Scheme (CBS) was introduced only in Salem district in 1992. Instead of resorting to female infanticide, parents who were unwilling to bring up their female babies could place them anonymously in cradles provided in various locations ${ }^{21}$. The babies would subsequently be offered for adoption. Between 1992 and 1996, 140 babies were placed in

\footnotetext{
${ }^{21}$ While the scheme is meant for female babies, sometimes male babies are also handed over to the scheme.
} 
government cradles in Salem (The Hindu, June 24, 2001). The scheme had a short life and following elections and a change of government in May 1996, it was shelved. ${ }^{22}$

In May 2001, the Cradle Baby Scheme was reintroduced. The new version of the scheme was initially launched in five districts but was soon extended to the entire state. The involvement of NGOs in scheme implementation and placement of the babies for adoption was enhanced. Frequent public announcements and advertisements in the press popularised the scheme, particularly in districts notorious for the practice of female infanticide. The scheme recorded a sharp increase in the number of babies and between May 2001 and November 2007, 2,410 baby girls had been received (see Table 5). The bulk of these babies were handed over in Salem and Dharmapuri.

To provide an idea of the role of the scheme in bringing down daughter deficit, consider that according to our analysis (see Table 2), post-birth daughter deficit fell from an annual shortfall of about 4,500 during the period $1996-99$ to about 1,800 in 2003 - a decline of about 2,700 babies. Over the 6.5 years between May 2001 and November 2007, on average the scheme received about 370 female babies per year. These figures suggest that the CBS may have accounted for about 14 percent (370/2700) of the reduction in post-birth daughter deficit observed between 1996-1999 and 2003.

Notwithstanding the scheme's apparent role in reducing daughter deficits and a recent proposal to extend it to every district in the country, the CBS has been criticised on various grounds. ${ }^{23}$

\footnotetext{
${ }^{22}$ Despite the low priority accorded to the scheme after 1996, babies continued to be surrendered, and between 1996 and 2001, 10 more babies were handed over. That is, a total of 150 babies were received in Salem district between 1992 and 2001 (see Table 5).

${ }^{23}$ Declaring the continued decline in the 0-6 sex ratio in various parts of the country to be a 'national emergency', the central government as part of its national child protection programme proposed a crèche in every district so that parents could leave their unwanted female babies in them (The Hindu, 22 February 2007). This has come under
} 
Immediate concerns are the state's capacity to settle the cradle babies in adopted homes and the survival rate of babies handed over to the CBS. While there is limited information on the fate of the babies after they are handed over to the scheme, according to information gathered during field work, in the first phase the mortality of babies surrendered to the CBS was about four times higher than the state's female IMR (Action Aid workshop in Delhi, 2007). A related concern is that the scheme feeds into a child trafficking network (Frontline, 22 (11), May 21-June 03, 2005; Bos, 2007).

More fundamentally, NGOs and activists have criticised the scheme on the grounds that it absolves parents of their responsibility towards their daughters and that it encourages son preference, as women can continue to 'dump the girl child in the cradles' till they have the desired number of sons (Sunday Magazine, January 06 2002). The Campaign against Sex selection (CASSA) rejects the CBS on the grounds that it violates the Convention on the Rights of the Child (CASSA, Cradle Baby Scheme, position note, May 2007). ${ }^{24}$

At the grassroots level the unpopularity of the scheme was based on a different issue, expressed in a popular (Tamil) saying: "We may give [children] to Yama [the Hindu God of death] but none to others [in adoption]" (Field work, Salem district, 2002). Surrendering a child threatens a man's image as a provider and protector, a sentiment reflected in responses such as, "If he [the household head] cannot bring up a daughter, is he a man?" (Field work, Salem district, 2002) Concerns about the quality of female life also appear to feature in the decision over whether to surrender or eliminate. These concerns are expressed in terms of the image of an ideal, "good"

severe criticism from civil society actors (The Hindu, 03 March 2007; Action Aid workshop in Delhi, December 2007).

${ }^{24}$ CASSA is a state-wide network of more than 60 NGOs whose main aim is to ensure effective implementation of the Pre-Conception and Pre-Natal Diagnostic Techniques (Prohibition of Sex Selection) Act (2003). CASSA's objection to the CBS is that the scheme violates Articles 7 and 9 of the UN Convention on the Rights of the Child. These articles deal with the child's right to be cared for by her biological parents and requires the State to ensure that children shall not be separated from their parents and in case of separation from one or both the parents, the State shall respect the rights of the child to maintain a personal relationship with both parents. 
mother and used to justify daughter elimination in preference to giving away unwanted daughters. The following response from one of the study villages illustrates this:

Only mothers who have got a child in wrong ways will surrender. A true mother will never have the heart to do so. She will say, "If the baby is killed, I will be upset for 2 days". But this is better than thinking, "Am I a mother? I gave away my offspring" (Field work, Salem district, 2002).

Countering these criticisms, government officials and NGOs involved in implementing the scheme argue that handing over babies to the scheme is a more humane option than murder and that the scheme offers the potential of a better life for unwanted babies. For example, having come under severe criticism for encouraging parents to surrender their daughters, the head of the district administration of Salem noted, "I asked the officials to stop receiving babies. Soon after, there were babies abandoned in gutters and garbage bins. We cannot let this happen. So we had to reopen the scheme" (Field work, Salem district, 2002). According to him, the scheme was not a permanent solution but acted only as a temporary safety valve and would be discontinued the day FI deaths stopped. Likewise, as one of the NGOs involved in adoption put it, "Instead of certain death, they (female babies) now have secure lives"(Trustee, Karnaprayag in Sunday Magazine, 06 January 2002). Considering the socio-cultural baggage that parents have to deal with in surrendering their unwanted daughters, a former senior government official noted that whatever criticisms may be directed at the scheme, the fact that many women chose to surrender rather than resort to female infanticide showed the courage of these women in challenging social ridicule (interview with a former Collector, Madurai district, April 2000; also Rajivan, 1998).

While the well-being and placement of "cradle babies" are issues that merit immediate and concerted attention, given the post-2001 increase in the number of female babies handed over to the scheme and the sharp reduction in daughter deficit during the same period, it does seem that the CBS has played an important role in reducing daughter elimination. 


\subsection{Legal action}

In 1992-93, the government decided to pursue legal action against those who committed or attempted female infanticide. Invoking the Right to Information Act, we obtained police records from each district (see Table 6). According to these records, the first arrests for female infanticide were made in Salem district in December 1992. Soon after, arrests and prosecution followed in Madurai (January 1994) and several arrests were made in Theni (January 1997 and February 1998) and Perambalur (1997). In the post-2001 phase police and legal action against infanticide registered an increase especially in Salem (five cases after 2001) and Theni (four cases after 2001) districts. Overall, ten cases of police and legal action were recorded between 2001 and 2003 as compared to seven cases between 1992 and 2000.

In terms of the effectiveness of a legal approach, the sharp decline in daughter deficit in districts (Salem and Theni) which witnessed a preponderance of the post-2001 arrests suggests that legal action is likely to have deterred female infanticide. A commonly encountered response in fieldwork in Salem during the post-2001 period is, "Killing of female infants used to happen earlier but not now. How can you? They will arrest you". Newspaper reports also suggest that fear of police action has led to a reduction in infanticide. ${ }^{25}$

Based on various rounds of field work and conversations with NGOs and government officials, it is clear that opinions on the efficacy and equity of using legal measures to curb daughter elimination are divided. Those in favour argue that pursuing legal action is the responsibility of the state and such actions serve as a strong deterrent. Those opposed to legal action argue that while it may yield limited short-term gains, such actions are typically directed at poor families which may leave them in debt while well-off families are not targeted. It is also argued that such

\footnotetext{
${ }^{25}$ For example, Rajam, a member of a self-help group in Omalur block of Salem, who had herself earlier killed her daughter, stated that it was fear of the police, more than anything else, that convinced villagers not to commit infanticide (The Hindu, April 10, 2004).
} 
actions treat the "victimised" mother as a criminal and can lead to unexpected consequences. ${ }^{26}$ These consequences have inspired a campaign against treating the mothers who kill their female babies as criminals. Indeed in a sharp reversal, NGOs such as the Indian Council for Child Welfare (ICCW), which helped file cases against female infanticide in Madurai, have over the years come to oppose legal action.

While the fairness of punishing mothers who may be compelled by their husbands or other family members to eliminate their daughters may be questioned, legal action is a clear signal of the state's unwillingness to tolerate infanticide. Based on the spatial patterns of decline in daughter deficit (sharp declines in Salem and Theni, which also witnessed the preponderance of legal action) and the responses recorded during our field work, it seems likely that the increased incidence of legal action after 2001 played an effective role in shaping the temporal decline in daughter deficit.

\subsection{Girl Child Protection Scheme}

The GCPS was launched in 1992. According to government documents, the aim of the scheme is to promote family planning, eradicate female infanticide and promote the welfare and status of girl children in poor families. The scheme is based on the assumption that because there is a perception of girls as an economic burden, it is necessary to enhance their economic value by providing financial support to families that raise girls. This is usually done in the form of depositing a certain sum of money in an interest-bearing security which is then used to provide

\footnotetext{
${ }^{26}$ Extreme examples of the consequences of legal action come from the cases of two women who attempted suicide and the case of Lakshmi, a mother from Theni district who committed suicide, when she was found guilty of infanticide (The Hindu, July 31, 2001). There are cases in which the women are reported to have returned from jail to find their husbands remarried or have been deserted or divorced. In situations where both parents have been arrested, children who are left behind have been neglected (Public hearing of the Tamil Nadu Women's Commission, July 2002; The Hindu, several issues).
} 
payments to households on a regular basis. ${ }^{27}$ The scheme is targeted at families below the poverty line, who have only daughters in the age group 0-4 and no sons, and one of the parents has undergone sterilization before the age of 35 years. During the first period of the scheme's operation (1992 to 1997), programme uptake was limited due to the meagre financial rewards and limited awareness about the programme and only 2,039 families made use of the scheme (Social Welfare Department, Government of Tamil Nadu).

In 2001-02 the GCPS was restructured to confer increased financial benefits, a 7 to 11 fold increase as compared to the earlier version of the programme, and the scheme's availability was widely publicised. ${ }^{28}$ A sum of Rs. 227 million, in real terms 2.83 times more than the allocation in 1991-92, was allocated for the scheme in 2001-02. The scheme witnessed a 50 fold increase in the number of beneficiaries. According to information from the public company holding the deposits, a sum of about Rs.1,750 million, benefiting 115,171 children, was disbursed by the scheme between 2001 and mid-2006.

While the number of beneficiaries has increased sharply, the effect of such a programme in altering attitudes towards girls and reducing daughter elimination is unclear. Available districtspecific data (see Table 7) show that the programme had beneficiaries from all the state's districts and that in the first two years of the restructured programme (2001-02 and 2002-03) only 15 percent of the beneficiaries were from the five high-infanticide districts of Dharmapuri, Madurai,

\footnotetext{
${ }^{27}$ In the first version of the scheme the government deposited Rs. 2000 on behalf of eligible families in an interestbearing fund. Money from this fund was to be paid out to families on occasions such as the first birthday of the child, on joining school and on joining class VI, with a terminal payment of Rs. 10,000 at the age of 20. A sum of Rs. 40 million per year was allocated for the scheme (Frontline, 19(03), Feb. 02-15, 2002).

${ }^{28}$ Currently, in the case of poor families with only one daughter and no son, and where either parent has undergone sterilization before the age of 35 years, the government deposits Rs.22,200 and in families with two girls and no sons, Rs.15,200 for each child, for 20 years in the Tamil Nadu Power Finance and Infrastructure Development Corporation. Interest accruing from this deposit provides monthly payments of about Rs.150 to the family and a terminal payment, at age 20, of Rs.80,000 for a one-girl family and a benefit of Rs.40,000 per girl for families with two girls. Based on income limits for scheme eligibility, the sum of Rs. 150 per month leads minimally to a 15 percent increase in income for families with two girls and a 4 percent increase for families with one girl.
} 
Salem, Theni and Namakkal, while 22 percent of the beneficiaries were from seven districts (Chennai, Coimbatore, Kancheepuram, Kanyakumari, Nilgiris, Thanjavur, Thiruvarur) where there is limited (or no) evidence of the practice. More formally, there is a very weak correlation (0.13) between the extent of daughter deficit in 1996-99 and the number of GCPS beneficiaries, suggesting that the programme was not targeted towards districts exhibiting a high prevalence of daughter deficit.

The principle of providing economic support to protect girls may be appropriate but the implementation of the scheme and the eligibility criteria suggest that the GCPS is unlikely to have achieved its objectives. First, as discussed above, the scheme is not targeted at districts with high rates of daughter deficit. Second, the GCPS targets families below the poverty line and frames daughter elimination as a problem amongst the poor. However, the existing evidence shows that daughter deficit is no more likely to occur in poor families and indeed may be more prevalent in better-off families. Based on regression analysis of data collected in 2002 from Salem district, Srinivasan and Bedi (2008) show that the probability of daughter elimination does not differ across castes and is not responsive to differences in income, wealth and education. Similarly, based on 1999-2000 National Sample Survey data, Siddhanta et al. (2003) find that there is no link between the female to male 0-14 sex ratio and per capita expenditure in rural Tamil Nadu. ${ }^{29}$ At a national level, data from the 2001 census reveals that the SRB is more likely to be masculine for mothers with more education (Bhat and Zavier, 2007). Education and prosperity appear to facilitate knowledge of, access to and the use of technology for sex selection (Agnihotri, 2003; Jha et al., 2006).

\footnotetext{
29 The finding that daughter deficit in rural Tamil Nadu is not influenced by income, expenditure, wealth, or education is relatively recent and underscores the widespread nature of the practice. This is in marked contrast to earlier findings which tended to find different patterns across the state. For instance, early work (George et al. 1992), based on data collected between 1987 and 1989 in Vellore district of Tamil Nadu pointed out that female infanticide was more likely to occur in remote villages with less educated populations. In contrast, Nillesen and Harriss-White's (2004) analysis, based on data collected in 1994 from Vellore and Thiruvanamallai districts, suggested that females were less likely to survive in wealthier households. A similar finding was reported by Vasanthi Devi (1991) in her study of female infanticide in Madurai district.
} 
Third, although participation in the programme is voluntary, the sterilization clause means that families with a strong son preference and who have only daughters are unlikely to be attracted to the scheme. The possibility that the scheme attracts those who do not have a strong son preference is consistent with the district-wise distribution of the larger share of GCPS beneficiaries in districts with limited evidence of daughter deficit.

Notwithstanding these shortcomings, similar schemes have been replicated by several state governments. While such cash transfers will certainly increase the ability of poor families to educate and take care of their girls and indeed other family members, it is unlikely that schemes such as the GCPS which focus only on the poor (while daughter elimination is more widespread) and impose sterilization as an eligibility requirement will have a substantial effect on reducing daughter deficits. ${ }^{30}$

\subsection{NGO strategies}

In addition to government interventions, several NGOs initiated activities against daughter elimination in the three heavily-affected districts of Madurai (including Theni), Salem (including Namakkal) and Dharmapuri, even before official recognition of the problem. ${ }^{31}$ While details differ across NGOs, NGO approaches consist broadly of three aspects (for details see Srinivasan, 2006). First, formation of women's self-help groups (SHGs) for savings and income generation and to tackle female infanticide explicitly. Second, identification, monitoring and counselling of high-risk pregnant women (those with more than one daughter and no son) and their families on the value of girl children. This is often done with the help of and through SHGs. When counselling, persuasion and emotional appeal fail, the threat of police action is

\footnotetext{
30 In addition to the state-wide interventions discussed above, in 1997-99, a special, one-off effort was made to tackle infanticide in Dharmapuri. The main idea was to tackle female infanticide through a process of social mobilization. A strong communication programme with kalaipayanams (itinerant street theatre) as its centerpiece was used to create awareness, highlight the value of girls and mobilize the population against female infanticide. Details are provided in Athreya and Chunkath (2000) and Chunkath and Athreya (2000).

31 Till January 1997, Theni was part of Madurai district, while Namakkal was part of Salem.
} 
invoked. Third, the provision of economic support for daughters and their families either through the NGO's own programmes or through government schemes. If these efforts are unsuccessful, surrendering the female baby to the CBS is offered as a last resort. Specific details on some of the main NGOs operating in Madurai and Salem are provided below.

The Indian Council for Child Welfare (ICCW) set up its office in the late 1980s in Usilampatti, Madurai (the region where female infanticide was first reported), with the main objective of rescuing female babies from infanticide. Along with its own version of the cradle baby scheme, girl child sponsorship and adolescent life skills training, it used the government's women's programme (mahalir thittam) to form self-help groups in villages to serve as a watchdog to monitor and prevent female infanticide. ${ }^{32}$ Group members were provided with training and other inputs on various aspects of gender discrimination including female infanticide, the status of women and girl children and women's rights. Every member took a vow that she would not practise or let others practise female infanticide. Locally recruited animators worked closely with the groups to implement the three-part approach outlined above. Through these measures, ICCW claims to have brought down the incidence of female infanticide in about 300 villages in Usilampatti block, from nearly 200 cases of female infanticide in 1991-92 to zero in 2002-03.

There are three main NGOs operating in various parts of Salem: the Community Services Guild (CSG) which started working on the issue in 1993 and broadly follows the approach outlined above; the Village Reconstruction and Development Program (VRDP) which began operations in 1996 and formed Kurinji, a network of like-minded NGOs and women's SHGs to monitor and prevent the practice of female infanticide in Salem (and Namakkal); and Poonthalir, which

32 Most of the women's self-help groups (SHGs) in Tamil Nadu are formed through the government's mahalir thittam (women's programme). The programme was initially funded by the International Fund for Agricultural Development (IFAD) and allowed for the formation of SHGs in five districts - Dharmapuri, Salem, South Arcot, Madurai and Ramanathapuran - with the help of NGOs between 1989 and 1998. By 2000 the programme had been extended to all the districts in the state and as of January 2003 there were 118,413 self-help groups operating in the state. 
commenced operations in 1998. Unlike other NGOs, Poonthalir relied mainly on its own staff rather than SHGs to prevent daughter elimination. The NGO targeted Idapadi, a block in Salem district with one of the highest incidence of female infanticide. As with the approach of other NGOs, Poonthalir staff identified high-risk pregnant women with the help of health and nutrition workers, SHG members and key informants. In addition, staff member were assigned to each primary health centre and hospital in the area to gather information on pregnant women. Subsequently, Poonthalir staff befriended and engaged in intensive rounds of monitoring and counselling with high risk women and their families. Where needed, Poonthalir offered economic support. If necessary, the NGO used the threat of police action and if all else failed it directed parents to the CBS. According to its records, between 1998 and 2008, Poonthalir had provided educational support to 350 girls, placed 350 girls for adoption, returned 25 girls surrendered to the CBS to their biological parents, prevented 1,157 cases of female infanticide by persuading parents not to surrender but to keep the girls in the families, and was instrumental in 10 to 15 arrests.

There are several notable aspects of the NGO interventions discussed above. First, unlike government interventions, NGO interventions are not as sensitive to changes in government and continued uninterrupted during the period 1992 to 2003. Second, as compared to state-wide government interventions, NGO efforts are specifically targeted at certain districts and also, within districts, NGOs tend to focus on those areas which exhibit the highest incidence of female infanticide. For instance, ICCW operated in two of Madurai district's 13 blocks; in Salem, CSG operated in five blocks while VRDP operated in three of the district's 20 blocks; and in Dharmapuri, AID's (Alternative for India Development) efforts were restricted to one of the district's 18 blocks. Third, while well-targeted, NGO monitoring operations are typically small in scale and restricted to a limited geographic area. 
The sharp decline in deficits after 2001, especially in districts such as Salem that have witnessed government and NGO attention, suggests that the scale and political will involved in the renewed government interventions combined with the intensity of the NGO grassroots targeted approach may have been the key to reducing daughter deficits. To illustrate these interactions, the penultimate section of the article takes a closer look at the experience of tackling daughter elimination in Salem district.

\section{Reactions and counter reactions: The case of Salem}

Salem district has the lowest (ie most masculine) sex ratio at birth and the highest daughter deficit in the state. Although interventions such as the CBS and legal action were launched in Salem in 1992, these were not sustained, and between 1996 and 2001 the government paid little attention to preventing daughter elimination in the district. Following the 2001 census, Salem was the focus of attention because it was the only district in south India with a 0-6 sex ratio below 850 . At the same time, a change in government brought the issue of daughter elimination back onto the public agenda.

Between June 2001 and July 2003, the Salem district administration adopted a zero-tolerance approach towards female infanticide, and worked closely with a wide range of district officials, health and nutrition workers and NGOs to prevent the practice. Several measures were taken. First, to demonstrate the zero-tolerance approach and the importance placed on the issue, district officials led by the Collector utilised every public opportunity to condemn female infanticide and sex selection. Officials and workers, particularly in the health and nutrition department, were held accountable for any infant death. Second, to enable village-level workers to provide information on female infanticide and sex selection without being ostracized by their communities, a 24-hour toll-free phone line was set up in the Collector's bungalow. Third, to monitor and counsel high-risk pregnant women, the NGO model was scaled up. SHGs were 
encouraged - and health and nutrition workers required - to monitor and prevent female infanticide; village-level committees, consisting of Panchayat members, SHG representatives, Village Health Nurses (VHN) and nutrition workers were set up in 385 of the district's 557 villages. Fourth, the CBS was re-energized, and, finally, arrests and subsequent legal action were stepped up - at least six cases of police and legal action were initiated during this period as compared to one during 1992-2000 (see Table 6).

Despite sustained efforts, some pockets in the district continued to report an exceptionally high female IMR and the threat of punishment appeared to be an inadequate deterrent. For example, the husband of a woman with three daughters trying for a son told a VHN,

What is the punishment [for female infanticide]? Two years? That's all no? Okay. We will kill the next one if it is a girl (Field work, Meicheri block, Salem district, 2002).

In other instances, government and NGO pressure led to changes in the manner in which daughters were eliminated and/or the manner in which the death was hidden. Initially, in the case of a female infanticide, parents falsified the cause of death. However, post-2001, any instance of a female infant death raised suspicion and led to exhumation and a post-mortem examination. ${ }^{33}$ Since suspicion was aroused only in the case of death of female infants, the sex of the dead infant began to be misreported. In some cases, the pregnancy itself was denied or families borrowed female babies and claimed them as their own till the pressure subsided. ${ }^{34}$

To counter such responses, the district administration began conducting a death audit for all infants - male and female. This in turn led to a change in the method of killing the female

\footnotetext{
${ }^{33}$ In Tamil Nadu, at least amongst Hindus, the customary funeral practice is to cremate adults and to bury babies and children.

${ }^{34}$ For example, in a case in Kolathur block in Salem the family denied that the woman in question was pregnant, despite the fact that the woman was registered and monitored throughout her pregnancy and it was the VHN who attended the childbirth at the Health sub-Centre (VHN discussion, Kolathur, 2002). In a similar case in Dharmapuri, a neighbouring district, the family enjoyed strong support from villagers, who feigned ignorance as well as surrounding the Collector and other district administrators, preventing them from investigating the case (The Hindu, 05 July 2000).
} 
infant — from poisoning or strangulation to a "natural" death due to neglect (starvation or being left in the open). Parents of the dead infant feigned ignorance - they did not know the infant was unwell and it was too late before they got medical attention. This forced the district administration to categorise neglect officially as a case of FI death (Discussion with medical officers, Kolathur block, Salem district, 2002). If death was due to a medical reason, parents had to produce proof that they had taken the infant to the doctor and that every attempt had been made to save the infant. In Meicheri block, discussion with a group of VHNs revealed that there were cases in which they reported FI deaths, but because parents produced false medical certificates no action could be taken. According to them, parents bribed private medical practitioners to issue false certificates listing a non-existent medical condition, the treatment provided and the outcome (death). Another strategy used to escape monitoring at the time of childbirth was for the expectant mother to travel to a neighbouring district or state where there was less surveillance to dispose of the infant, if female, with relative ease. ${ }^{35}$

Notwithstanding the reactions and counter-reactions, the figures suggest that post-2001 the range of interventions adopted in Salem was successful in reducing daughter deficit. During the period May 2001 to November 2007, the Salem CBS received 665 babies, compared with the 150 babies received during the first phase of the scheme. Overall, as shown in Table 2, between 1996-99 and 2003, female IMR in Salem dropped drastically from 121 to 45, supporting the district administration's claim that their efforts had led to a reduction in female infant mortality/infanticide. ${ }^{36}$

\section{Concluding remarks and discussion}

\footnotetext{
35 The surveillance also led to a breakdown of trust. There were instances in which, due to enmity or jealousy, neighbours or other individuals in the village used the anonymous hotline to report false cases of female infant death. For more details see Srinivasan (2006).

${ }^{36}$ Salem district won accolades from the Chief Minister each year during the second phase for its efforts to tackle female infanticide.
} 
This article has provided a temporal and spatial analysis of daughter deficits in Tamil Nadu over the period 1996 to 2003 and undertook an examination of the modus operandi, underlying assumptions, strengths and weaknesses of various interventions that have been used in the state to prevent daughter elimination. Total daughter deficit in 1996-1999, a period characterized by a lull in government interventions, amounted to an annual shortfall of about 11,000 daughters. Following a change of government, the period after May 2001 was marked by an increase in efforts to prevent daughter elimination. Our analysis showed that in 2003, daughter deficit declined to about 7,100. The decline between 1996-1999 and 2003 was driven mainly by a sharp reduction in post-birth daughter deficit. The sharpest reductions were recorded in Salem and Dharmapuri. These districts displayed the highest incidence of pre- and post-birth deficit in 1996-1999 and were the focus of various government and NGO initiatives to prevent daughter elimination.

The fact that the decline in post-birth deficit was particularly pronounced in those districts that had a concentration of government and NGO interventions supports the idea of a link between the various efforts and the declining deficit. To reiterate, while we do not claim to provide an impact evaluation of the schemes and it is possible that factors unrelated to the programmes may have played a role in reducing deficits, the statistical analysis provided in the article, combined 
with information collected during several rounds of field work, yields important insights. ${ }^{37}$ First, the Cradle Baby Scheme serves as a safety valve and may account for about 14 percent of the decline in post-birth daughter deficit. Second, it is unlikely that the Girl Child Protection Scheme has played a substantial role in preventing daughter elimination. The GCPS is not appropriately targeted and the imposition of sterilization is unlikely to have attracted families with a strong son preference. The analysis presented here suggests that if schemes such as the GCPS are to play a role in reducing daughter deficit it is important to remove the sterilization requirement and to find ways to extend the scheme beyond the poor. Third, despite the uninterrupted operations of NGOs, the reduction in daughter deficit mainly in the post-2001 period suggests that without the scale, support and will of the government, NGO interventions are unlikely to lead to a widespread decline in daughter deficit. Likewise, legal action and state-wide schemes such as the CBS and the GCPS, unless they are linked to a grassroots approach, are unlikely to lead to a reduction in daughter deficit. Finally, the sharp decline in daughter deficit precisely in those districts that had a combination of government and NGO interventions suggests that widespread monitoring and counselling of high risk mothers at the grassroots level through a network of NGOs, SHGs and health and nutrition workers, linked to the credible threat of legal action and some form of economic support to high risk families, may comprise an effective intervention model.

37 It is quite possible that there may be several factors other than the interventions, which may have led to a reduction in deficits. As pointed out in the introduction we do not make causal claims. It is difficult to do so, as a number of the interventions operate state-wide and were introduced at the same time. In terms of the language of impact evaluation, while we can construct a before-after comparison we cannot easily construct a treatment group and a control group. However, to get as close as possible to the notion of a before-after (1996-1999 versus 2003) and treatment-control setting we divided the state's 28 districts into those which were heavily treated (ie, received all the interventions - CBS, legal action, GCPS and NGO interventions), lightly treated (CBS, legal action and GCPS) and minimally treated (CBS and GCPS). Subsequently, we used district-level data before and after the interventions, controlled for various other factors, such as changes in per capita income, increases in male and female labour force participation, increases in the number of female self-help groups or more favourable weather conditions, and used difference-in-differences regressions to examine the effect of being heavily and lightly treated on daughter deficits. The results are provided in Table A1. Consistent with the analysis presented in the main body of the article, the estimates show that there is a strong link between being "heavily treated" and post-birth deficit reduction while there is no link between being "heavily treated" and pre-birth deficit. The regressions confirm the idea that while other factors do play a role, the reduction in post-birth daughter deficit emanates mainly from heavily treated districts and that it is the combination of interventions which is effective in reducing post-birth deficit. A comparison of the decline in the magnitude of the post-birth deficit between 1996-1999 and 2003 (a decline from about 35 girls per 1000 boys to 10) with the coefficient on "heavily treated" suggests that the interventions are responsible for about 88 percent of the observed decline in post-birth deficit in heavily-treated districts. 
The decline in daughter deficit over this period has come mainly from a reduction in female infanticide. An obvious concern is that over this period post-birth daughter deficit may have been replaced by pre-birth deficit. However, our analysis showed that between 1996-99 and 2003, pre-birth daughter deficit does not appear to have increased even as post-birth daughter deficit declined. This is supported by information obtained during field work in Salem in 2007 and 2008, where NGOs and health and nutrition workers pointed to a decline in the prevalence of female infanticide as well as in sex selection. For instance, the director of VRDP stated that,

Sex selection has definitely come down as we are constantly watching the scan centres. We know the centres where there is malpractice and we are watching these closely and hope that some day we can catch them (Field work, Salem district, 2008).

A second concern is whether the observed decline in daughter deficit is temporary or whether there has been a structural change. It is unlikely that the interventions will have succeeded in altering underlying factors that lead to son preference and daughter aversion, and indeed none of the interventions are geared towards addressing kinship/marriage norms and dowry practices. Hence, it is quite possible that a reduction in government interest in preventing daughter elimination will lead to a rise in daughter deficit (a change of government took place in 2006). While a new round of VES/census is required to provide a more detailed district-level assessment after 2003, state level SRS-based IMR figures and discussions during field work in 2007 and 2008 suggest that an environment favourable to daughters is still a distant prospect. For instance, Table A2 shows a clear decline in male-female differences in infant mortality in 2002, 2003 and 2004. However, in 2005 and beyond, these differences appear to return to the levels observed in 1999. In addition, the following excerpts illustrate that while the effects of the interventions are perceptible, daughter elimination still continues:

Illustration 1 (Discussion with an elderly woman, field work, Sankari block, Salem district, 2007) My daughter-in-law had twin daughters from her first pregnancy. When she was pregnant again we went to a doctor in Bhavani (in the neighbouring district). We explained that with two daughters we could not afford to have any more daughters. Initially the doctor refused to even see us. But we waited and pleaded. She finally agreed but only after repeated assurances that we would not breathe a word to anyone. She said, "I'm trying to help you. Please understand that my name or my clinic's should not be brought to disrepute". 
Illustration 2 (Discussion with a VHN, Field work, Sankari Block, Salem district, 2007)

On giving birth to her second daughter, the faces of the mother and her mother-in-law became small. I stayed up till about 4.00a.m. to cheer her up. Later in the day I visited her house. Next to the woman, her three-year old daughter was trying to stuff a loaf of bread into the newborn's mouth. I rushed in and grabbed the newborn. I was very angry and asked the woman "How could you let this happen to the newborn"? She replied, "I was so engrossed in the conversation that I did not notice what was happening". She went on to add, "Why are you making such a scene? People in Erode are getting rid of unwanted babies. So what if I get rid of her"? I said, "Try doing any such thing and you will land in prison as I will lodge a police report against you. If you don't want the child, you can give it to the CBS. But you are not going to kill her".

Illustration 3 (Discussion with Poonthalir staff, Idapadi block, Salem district, 2008)

Researcher: Will female infanticide occur if Poonthalir were not around?

Staff 1: Yes. Now they don't do it out of fear.

Staff 2: When we don't go to a village for one or two months, people think our office is closed or we have moved to another area and try to commit female infanticide.

While the sustainability of the reduction in daughter deficit is in doubt, the analysis presented here shows that daughter elimination is amenable to public policy. 


\section{References}

Agnihotri, B. Satish (2003) Survival of the girl child: Tunnelling out of the Chakravyuha, Economic and Political Week.ly, 38(41): 4351- 4360.

Athreya, Venkatesh (1999) A report on the vital events surveys, Chennai, Mimeo.

Athreya, Venkatesh and Sheela Rani Chunkath (2000) Monitoring the health sector, Frontline, 16(27), Dec.25, 1999 - Jan.07, 2000.

AIDWA (2003) Expanding dimensions of dowry. New Delhi: All India Democratic Women's Association.

Bardhan, Pranab (1974) On life and death questions, Economic and Political Weekly, 9(32, 33 \& 34): 1293-1304.

Bardhan, Pranab (1982) Little girls and death in India, Economic and Political Weekly, 17(36): 14481450.

Basu, M. Alaka (1999) Fertility decline and increasing gender imbalance in India, including a possible south Indian turnaround, Development and Change 30(2): 237-263.

Bhat, Mari and A.J. Francis Zavier (2007) Factors influencing the use of prenatal diagnostic techniques and the sex ratio at birth in India, Economic and Political Weekly, 42(23): 2292-2303.

Bos, Pien (2007) Once a mother. Relinquishment and adoption from the perspective of unmarried mothers in south India. PhD dissertation. Nijmegen University.

Croll, Elizabeth (2000) Endangered daughters: Discrimination and development in Asia. London and New York: Routledge.

Chunkath, Sheela Rani and V.B.Athreya (1997) Female infanticide in Tamil Nadu-Some evidence, Economic and Political Weekly, 32(17): WS-21-28.

Chunkath, Sheela Rani and V.B.Athreya (2000) Tackling female infanticide: social mobilization in Dharmapuri, 1997-99, Economic and Political Weekly, 36(49): 4345-4348.

Chung, Woojin and Monica Das Gupta (2007) The decline of son preference in South Korea: The roles of development and public policy, Population and Development Review, 33 (4): 757-783.

Dyson, Tim and Mick Moore (1983) On Kinship Structure, Female Autonomy and Demographic Behaviour in India, Population and Development Review, 9(1): 35-60.

George, Sabu, Abel, Rajaratnam and Miller, Barbara (1992) Female infanticide in rural South India, Economic and Political Weekly, 27 (22): 1153-1156.

Guilmoto, Christophe (2009) The sex ratio transition in Asia, Population and Development Review, 35(3): 519-549. 
Heyer, Judith (1992) The role of dowries and daughters' marriages in the accumulation and distribution of capital in a South Indian community Journal of International Development, 4 (4): 419-436.

Hill, Kenneth and Dawn Upchurch (1995) Gender differences in Child Health: Evidence from the Demographic and Health Surveys, Population and Development Review, 21(1): 127-151.

Jeeva, M., Gandhimathi, A. and Phavalam, P. (1998) Female infanticide-philosophy, perspective and concern of SIRD, Search Bulletin, 13(3): 9-17.

Jha, Prabhat, Rajesh Kumar, Priya Vasa, Neeraj Dhingra, Deva Thiruchelvam, Rahim Moineddin (2006) Low male-to-female sex ratio of children born in India: National survey of 1.1 million households in Lancet, Published online January 9, 2006, DOI:10.1016/S0140-6736(06)679300 , www.thelancet.com.

Johansson, Sheila Ryan (1984) Deferred infanticide: Excess female mortality during childhood, in Glenn Hausfater and Sarah Blaffer Hrdy (eds.) Infanticide: Comparative and evolutionary perspectives, pp. 463-486. New York: Aldine.

Johansson, Sten and Ola Nygren (1991) The missing girls of China: A new demographic account, Population and Development Review, 17(1): 35-51.

Kapadia, Karin (1993) Marrying money: Changing preference and practice in Tamil marriage, Contributions to Indian Sociology, 27(1), 25-51.

Kapadia, Karin (1995) Siva and her sisters. Gender, caste and class in rural south India. Boulder, San Francisco and Oxford: Westview Press.

Li Shuzhuo (2007) Imbalanced sex ratio at birth and comprehensive intervention in China, $4^{\text {th }}$ Asia Pacific conference on reproductive and sexual health and rights, Hyderabad, India.

Miller, Barbara (1981) The endangered sex: Neglect of female children in rural north India. Ithaca and London: Cornell University Press.

Miller, Barbara (1989) Changing Patterns of Juvenile Sex Ratios in Rural India, 1961 to 1971, Economic and Political Weekly, 24(22): 1229-36.

Narayana, D. (2008) Intensifying infant mortality inequality in India and a reversal by policy intervention, Journal of Human Development, 9(2): 265-281.

Nillesen, Paul H.L. and Barbara Harriss-White (2004) Life chances: Development and female disadvantage in Barbara Harriss-White and S.Janakarajan (eds.) Rural India facing the $21^{\text {st }}$ century. Essays on long term village change and recent development policy, pp.328-348. London: Anthem Press.

Office of the Registrar General, Government of India (2007) SRS Baseline Survey Report 2004. New Delhi.

Rajivan, K. (1998) Life and death for her, Search Bulletin, 13 (3): 75-77. 
Retherford, Robert D. and T.K. Roy (2003) Factors affecting sex-selective abortion in India and 17 major states, National Family Health Survey Subject Reports. Mumbai, India: International Institute for Population Sciences.

Sen, Amartya (1990) More than 100 million women are missing, The New York Review of Books, December 20.

Siddhanta, S., Nandy, D. and Agnihotri, S.B. (2003) Sex ratios and 'prosperity effect': what do NSSO data reveal? Economic and Political Weekly, 38(41): 4381-4404.

Sopher, D E (1980) The Geographical Patterning of Culture in India in D E Sopher (ed.), An Exploration of India: Geographical Perspectives on Society and Culture, pp 289-326. London: Longman.

Soundarapandian, A. (1985) Varadatchanaikkup payandu pen kuzhandaigalai kolgirargal. Junior Vikatan, 4 December [in Tamil].

Srinivasan, Sharada (2005) Daughters or dowries? The changing nature of dowry practices in South India, World Development, 33(4): 593-615.

Srinivasan, Sharada (2006) Development, discrimination and survival. Daughter elimination in Tamil Nadu, India. Maastricht: Shaker Publications.

Srinivasan, Sharada and Arjun Singh Bedi (2008) Daughter Elimination in Tamil Nadu, India: A Tale of Two Ratios, Journal of Development Studies, 44 (7): 929-958.

Srinivasan, Sharada and Arjun Singh Bedi (2009) Tamil Nadu and the Diagonal Divide in Sex Ratios, Economic and Political Weekly, 44(3): 56-63.

State Planning Commission (2005) Round Table Discussion on Human Development \& Agriculture Diversification and Water Resources Management, 18 - 19, May 2005, (mimeo). Chennai: State Planning Commission. http://www.tn.gov.in/spc/workshop/6HD $\% 20$ and $\% 20$ Health-SEC.PPT, accessed on 30 October 2007.

Vasanthi Devi, V. (1991) Socioeconomic context of female infanticide: a study of Usilampatti taluk in Tamil Nadu, paper presented to the 5th National Conference on Women's Studies, Calcutta.

Venkatramani, S. (1986) Born to die. India Today, 15 June, pp. 26-33.

Venkatachalam, R. and Srinivasan, V. (1993) Female Infanticide. New Delhi: Har-Anand Publications.

Visaria, P. M. (1967) The Sex Ratio of the Population of India and Pakistan and Regional Variations during 1901-61 in A Bose (ed.) Patterns of Population Change in India, 1951-61.

Bombay: Allied Publishers.

Waldron, Ingrid (1983) Sex differences in human mortality: The role of genetic factors, Social Science and Medicine, 17(6): 321-333. 
Table 1

Infant Mortality Rates in Tamil Nadu

\begin{tabular}{|c|c|c|c|c|c|c|c|c|c|}
\hline \multirow[t]{2}{*}{ Year/Statistic } & \multicolumn{3}{|c|}{$\begin{array}{c}\text { IMR } \\
\text { Tamil Nadu }\end{array}$} & \multicolumn{3}{|c|}{$\begin{array}{c}\text { IMR } \\
\text { Urban Tamil Nadu }\end{array}$} & \multicolumn{3}{|c|}{$\begin{array}{c}\text { IMR } \\
\text { Rural Tamil Nadu }\end{array}$} \\
\hline & Male & Female & $\begin{array}{l}\text { Expected } \\
\text { Female }\end{array}$ & Male & Female & $\begin{array}{c}\text { Expected } \\
\text { Female }\end{array}$ & Male & Female & $\begin{array}{l}\text { Expected } \\
\text { Female }\end{array}$ \\
\hline \multirow{2}{*}{$\begin{array}{l}\text { 1996-1999 } \\
\text { Absolute value of test statistic } \\
\text { p-value }^{a}\end{array}$} & 36 & 39 & 28.8 & 23 & 19 & 18.4 & 41 & 48 & 32.8 \\
\hline & \multicolumn{3}{|c|}{$\begin{array}{c}23.5 \\
(0.000)\end{array}$} & \multicolumn{3}{|c|}{$\begin{array}{c}1.01 \\
(0.313)\end{array}$} & \multicolumn{3}{|c|}{$\begin{array}{c}26.8 \\
(0.000) \\
\end{array}$} \\
\hline \multirow{2}{*}{$\begin{array}{l}2003 \\
\text { Absolute value of test statistic } \\
\text { p-value }\end{array}$} & 30 & 29.7 & 24 & 24 & 21 & 19.2 & 32.6 & 33.1 & 26.1 \\
\hline & \multicolumn{3}{|c|}{$\begin{array}{c}7.20 \\
(0.000)\end{array}$} & \multicolumn{3}{|c|}{$\begin{array}{c}1.43 \\
(0.152)\end{array}$} & \multicolumn{3}{|c|}{$\begin{array}{c}7.11 \\
(0.000) \\
\end{array}$} \\
\hline $\begin{array}{l}\text { Change in dIMR (1996-1999 to 2003) } \\
\text { Absolute value of test statistic } \\
\text { p-value }\end{array}$ & \multicolumn{3}{|c|}{$\begin{array}{c}4.5 \\
17.15 \\
(0.000)\end{array}$} & \multicolumn{3}{|c|}{$\begin{array}{c}-1.2 \\
8.33 \\
(0.000) \\
\end{array}$} & \multicolumn{3}{|c|}{$\begin{array}{c}8.2 \\
21.6 \\
(0.000) \\
\end{array}$} \\
\hline
\end{tabular}

Notes: Infant mortality rate (IMR) is defined as the number of infant deaths (age 0-365 days) per 1000 live births. All calculations are based on the Vital Events Surveys 1996-1999 and 2003. ${ }^{a} H_{0}$ : estimated female IMR is greater than the expected female IMR (0.8*MIMR). ${ }^{b} H_{0}$ : temporal change in difference between estimated female IMR and expected female IMR (dIMR) is zero. 
Table 2

District-specific Male and Female Infant Mortality Rates and Post-birth Daughter Deficit

Tamil Nadu, 1996-1999 and 2003

\begin{tabular}{|c|c|c|c|c|c|c|c|c|}
\hline & $\begin{array}{c}\text { MIMR } \\
\text { Rural } \\
\text { 1996-99 } \\
\text { (1) }\end{array}$ & $\begin{array}{c}\text { FIMR } \\
\text { Rural } \\
1996-99 \\
\text { (2) }\end{array}$ & $\begin{array}{c}\text { MIMR } \\
\text { Rural } \\
2003 \\
(3)\end{array}$ & $\begin{array}{c}\text { FIMR } \\
\text { Rural } \\
2003 \\
(4)\end{array}$ & $\begin{array}{c}\text { Overall } \\
\text { Deficit } \\
1996-1999 \\
5\end{array}$ & $\begin{array}{c}\text { Overall } \\
\text { Deficit } \\
2003 \\
6\end{array}$ & $\begin{array}{c}\text { Rural } \\
\text { Deficit } \\
1996-1999 \\
7\end{array}$ & $\begin{array}{c}\text { Rural } \\
\text { Deficit } \\
2003 \\
8\end{array}$ \\
\hline Tamil Nadu &. & 1, & . & (1) & 4485 & 1829 & 4017 & 1799 \\
\hline Chennai & . & & . & . & 0 & 2 & . & . \\
\hline Coimbatore & 39 & 30 & 25 & 21 & 0 & 11 & 0 & 2 \\
\hline Cuddalore & 37 & $36^{*}$ & 32 & 35 & $85^{*}$ & 98 & $78 *$ & $110^{*}$ \\
\hline Dharmapuri & 56 & $111 *$ & 45 & $49 *$ & $1189 *$ & $219 *$ & $1311 *$ & $258^{*}$ \\
\hline Dindigul & 43 & $56^{*}$ & 30 & $54 *$ & $222 *$ & $289 *$ & $177 *$ & $241 *$ \\
\hline Erode & 41 & $41 *$ & 34 & 28 & $89 *$ & 0 & $60 *$ & 3 \\
\hline Kancheepuram & 30 & 25 & 23 & 22 & 24 & 58 & 6 & 31 \\
\hline Kanyakumari & 20 & 19 & . & & 28 & . & 15 & . \\
\hline Karur & 43 & $41 *$ & 37 & 35 & $38^{*}$ & 41 & $28^{*}$ & 22 \\
\hline Madurai & 41 & $58^{*}$ & 30 & $42^{*}$ & $311 *$ & $230^{*}$ & $198^{*}$ & $138^{*}$ \\
\hline Nagapattinam & 37 & 34 & 34 & 30 & $45^{*}$ & 40 & 46 & 24 \\
\hline Namakkal & 43 & $60 *$ & 31 & 26 & $135^{*}$ & 4 & $132 *$ & 7 \\
\hline Nilgiris & 41 & 35 & 32 & 24 & 7 & 12 & 6 & 0 \\
\hline Perambalur & 47 & $51 *$ & 31 & $38^{*}$ & $52^{*}$ & $49 *$ & $45^{*}$ & $42^{*}$ \\
\hline Pudukottai & 36 & $38^{*}$ & 31 & $35^{*}$ & $66^{*}$ & $92^{*}$ & $91 *$ & $97 *$ \\
\hline Ramanathapuram & 51 & $47 *$ & 37 & 31 & 28 & 36 & $48^{*}$ & 11 \\
\hline Salem & 49 & $121 *$ & 35 & $45^{*}$ & $1067 *$ & $283^{*}$ & $844^{*}$ & $178^{*}$ \\
\hline Sivaganga & 34 & $36^{*}$ & 28 & 24 & $45^{*}$ & 0 & $47^{*}$ & 8 \\
\hline Thanjavur & 43 & 34 & 38 & 26 & 0 & 0 & 0 & 0 \\
\hline Theni & 48 & $81 *$ & 35 & $42^{*}$ & $227 *$ & $88^{*}$ & $137 *$ & $46^{*}$ \\
\hline Thirunelveli & 39 & 35 & 36 & 32 & $101 *$ & 59 & 47 & 42 \\
\hline Thiruvallur & 31 & $30^{*}$ & 28 & 24 & 48 & 35 & $46^{*}$ & 13 \\
\hline Thiruvannamalai & 38 & $42^{*}$ & 32 & 34 & $110^{*}$ & 82 & $149 *$ & 107 \\
\hline Thiruvarur & 39 & 32 & 34 & 19 & 0 & 0 & 2 & 0 \\
\hline Thuthukudi & 45 & 40 & 33 & 30 & 24 & 37 & 31 & 27 \\
\hline Tiruchirapalli & 52 & $48^{*}$ & 29 & $42 *$ & $98 *$ & $230^{*}$ & $58^{*}$ & $182 *$ \\
\hline Vellore & 42 & $56^{*}$ & 36 & $48^{*}$ & $395^{*}$ & $349 *$ & $367 *$ & $312 *$ \\
\hline Villupuram & 48 & $45^{*}$ & 32 & $36^{*}$ & $113^{*}$ & 143 & $137 *$ & $195^{*}$ \\
\hline Virudhunagar & 39 & $40^{*}$ & 38 & 31 & $96^{*}$ & 37 & $64 *$ & 3 \\
\hline
\end{tabular}

Notes: Infant mortality rate (IMR) is defined as number of infant deaths (age 0-365 days) per 1000 live

births. The IMR figures are our calculations based on the Vital Events Surveys, 1996-1999. * indicates that the estimated female IMR is greater than the expected female IMR at at least the $5 \%$ level of significance. 
Table 3

District-specific Sex Ratios at Birth

(95\% C.I.)

\begin{tabular}{|c|c|c|c|c|c|c|c|c|c|}
\hline \multirow[t]{2}{*}{ District } & \multicolumn{3}{|c|}{ Overall } & \multicolumn{3}{|c|}{ Urban } & \multicolumn{3}{|c|}{ Rural } \\
\hline & $\begin{array}{c}\text { 1996-1999 } \\
\text { VES } \\
(1)\end{array}$ & $\begin{array}{c}2001 \\
\text { Census } \\
(2)\end{array}$ & $\begin{array}{l}2003 \\
\text { VES } \\
(3)\end{array}$ & $\begin{array}{c}\text { 1996-1999 } \\
\text { VES } \\
(4)\end{array}$ & $\begin{array}{c}2001 \\
\text { Census } \\
(5)\end{array}$ & $\begin{array}{c}2003 \\
\mathrm{VES} \\
(6)\end{array}$ & $\begin{array}{c}\text { 1996-1999 } \\
\text { VES } \\
(7)\end{array}$ & $\begin{array}{c}2001 \\
\text { Census } \\
(8)\end{array}$ & $\begin{array}{l}2003 \\
\text { VES } \\
(9)\end{array}$ \\
\hline Tamil Nadu & $935(931-940)^{*}$ & 935 & 944 (935-953) & $943(935-952)$ & 960 & $954(935-971)$ & $932(927-937)^{*}$ & 919 & $940(929-951)^{* *}$ \\
\hline Chennai & 947 (921-973) & 979 & $970(916-1028)$ & 947 (921-973) & 979 & 970 (916-1028) & - & & \\
\hline Coimbatore & 950 (927-973) & 963 & $928(885-973)$ & 999 (953-1047) & 964 & 904 (819-997) & 932 (906-959) & 961 & 935 (886-987) \\
\hline Cuddalore & $946(922-970)$ & 930 & 953 (907-1001) & $956(912-1000)$ & 932 & 979 (890-1077) & 941 (913-970) & 929 & $943(890-1000)$ \\
\hline Dharmapuri & $922(902-942) *$ & 869 & 931 (888-976) & 958 (918-1001) & 936 & 945 (860-1037) & $909(886-933) *$ & 859 & $926(876-978)$ \\
\hline Dindigul & $922(900-944) *$ & 934 & 950 (901-1001) & $936(893-981)$ & 955 & $1006(913-1109)$ & $917(891-943) *$ & 923 & 926 (870-987) \\
\hline Erode & $928(904-953)^{* *}$ & 934 & 942 (892-994) & 950 (905-999) & 962 & 985 (888-1093) & $919(890-948) *$ & 910 & 926 (868-987) \\
\hline Kancheepuram & 946 (924-969) & 949 & 931 (890-974) & 951 (907-997) & 964 & 951 (861-1050) & 945 (920-970) & 934 & $926(881-974)$ \\
\hline Kanyakumari & 948 (922-975) & 988 & & 933 (884-985) & 1000 & $956(865-1057)$ & 953 (923-985) & 968 & . \\
\hline Karur & 893 (869-917)* & 910 & 928 (879-979) & $870(826-916) *$ & 941 & 984 (884-1095) & $901(873-930)^{*}$ & 895 & 909 (854-968) \\
\hline Madurai & $924(902-947) *$ & 951 & $922(878-968)$ & $918(876-960)$ & 973 & 911 (830-1000) & $927(901-954)^{* *}$ & 925 & $926(875-981)$ \\
\hline Nagapattinam & $928(905-952)^{* *}$ & 982 & $987(938-1038)$ & 916 (874-959) & 975 & 978 (891-1073) & 934 (906-963) & 984 & $990(932-1052)$ \\
\hline Namakkal & $911(887-934)^{*}$ & 859 & $903(856-952)^{*}$ & 932 (888-977) & 916 & 906 (816-1105) & $902(874-930)^{*}$ & 829 & $901(847-960)^{* *}$ \\
\hline Nilgiris & 959 (930-990) & 988 & $964(902-1029)$ & 955 (905-1008) & 963 & 1007(896-1131) & $962(925-1000)$ & 1023 & 943 (871-1022) \\
\hline Perambalur & $932(906-960)$ & 896 & $943(888-1000)$ & . & 903 & & $932(906-960)$ & 894 & 943 (888-1000) \\
\hline Pudukottai & 947 (925-970) & 935 & $926(882-972)$ & 917 (876-959) & 879 & 978 (887-1076) & 959 (932-986) & 945 & 909 (859-962) \\
\hline Ramanathapuram & 949 (925-975) & 990 & $922(875-971)$ & 943 (899-987) & 1019 & $953(865-1050)$ & 952 (923-982) & 981 & 909 (853-968) \\
\hline Salem & $874(852-896) *$ & 838 & $899(853-947)^{*}$ & 943 (902-985) & 880 & 912 (827-1005) & $843(817-869)^{*}$ & 806 & $893(839-951)^{*}$ \\
\hline Sivaganga & 934 (910-959) & 955 & $976(927-1026)$ & $962(916-1009)$ & 952 & 966 (880-1059) & $923(894-952)^{* *}$ & 956 & $980(922-1041)$ \\
\hline Thanjavur & $939(916-963)$ & 962 & $981(932-1032)$ & $965(919-1012)$ & 994 & 931 (843-1027) & $929(902-958)$ & 948 & $1000(942-1060)$ \\
\hline Theni & $932(909-956)^{* *}$ & 895 & $960(913-1012)$ & $921(878-965)$ & 924 & 983 (894-1080) & 937 (910-964) & 862 & 952 (895-1012) \\
\hline Thirunelveli & $925(902-948)^{*}$ & 946 & 939 (893-988) & 924 (886-966) & 944 & 894 (817-977) & $925(898-954)^{* *}$ & 948 & 962 (904-1023) \\
\hline Thiruvallur & 945 (922-967) & 953 & $974(930-1020)$ & 938 (896-982) & 971 & 902 (822-989) & 947 (920-974) & 936 & $1000(948-1054)$ \\
\hline Thiruvannamalai & 957 (932-982) & 922 & 924 (877-973) & $966(922-1011)$ & 1016 & 940 (854-1033) & 953 (923-983) & 905 & 917 (862-976) \\
\hline Thiruvarur & 959 (935-984) & 967 & 934 (887-984) & $973(927-1020)$ & 999 & 977 (887-1075) & 954 (925-983) & 960 & 917 (861-976) \\
\hline Thuthukudi & 965 (939-992) & 956 & $1022(969-1078)$ & 992 (943-1041) & 977 & 1048(953-1153) & 954 (923-985) & 941 & $1010(947-1078)$ \\
\hline Tiruchirapalli & $945(921-970)$ & 951 & $932(883-982)$ & $961(915-1008)$ & 964 & $1009(914-1113)$ & $939(910-968)$ & 941 & $901(846-960)^{* *}$ \\
\hline Vellore & 952 (929-975) & 907 & 923 (878-969) & 958 (914-1004) & 951 & 961 (874-1056) & 950 (923-977) & 885 & 909 (859-963) \\
\hline Villupuram & 958 (935-982) & 938 & 947 (902-994) & $946(920-1021)$ & 955 & 933 (848-1025) & $963(935-991)$ & 936 & 952 (890-1008) \\
\hline Virudhunagar & $908(886-931)^{*}$ & 945 & 955 (908-1003) & $880(837-923)^{*}$ & 966 & $859(778-948)^{*}$ & $919(893-946) *$ & 930 & $990(935-1049)$ \\
\hline
\end{tabular}

Notes: The sex ratio at birth (SRB) is defined as the number of female live births per 1000 male live births. The SRB figures are our calculations based on the Vital Events Surveys (VES), 1996-1999. *, ** indicate that the SRB is statistically different from the expected SRB of 952, at the 5\% and 10\% level of significance, respectively. 
Table 4: Pre-Birth Daughter Deficit

\begin{tabular}{|c|c|c|c|c|c|c|}
\hline \multirow[t]{2}{*}{ District } & \multicolumn{3}{|c|}{ Overall } & \multicolumn{3}{|c|}{ Rural } \\
\hline & $\begin{array}{c}\text { 1996-1999 } \\
\text { VES } \\
\text { (1) }\end{array}$ & $\begin{array}{l}2003 \\
\text { VES } \\
(2)\end{array}$ & $\begin{array}{c}\text { Change } \\
\text { 1996-1999 to } 2003 \\
\text { VES (p-value) } \\
\text { (3) }\end{array}$ & $\begin{array}{c}\text { 1996-1999 } \\
\text { VES } \\
\text { (4) }\end{array}$ & $\begin{array}{c}2003 \\
\text { VES } \\
(5)\end{array}$ & $\begin{array}{c}\text { Change } \\
\text { 1996-1999 to } 2003 \\
\text { VES (p-value) } \\
(6)\end{array}$ \\
\hline Tamil Nadu & $6244^{a}$ & $1563^{a}$ & b $124(0.453)$ & $4386^{\mathrm{a}}$ & $1514^{a}$ & $1068^{b}$ \\
\hline Chennai & 124 & 0 & $-612(0.390)$ & & . & \\
\hline Coimbatore & 53 & 665 & $108(0.789)$ & 185 & 158 & $27(0.914)$ \\
\hline Cuddalore & 108 & 0 & $222(0.711)$ & 133 & 113 & $20(0.956)$ \\
\hline Dharmapuri & $756^{*}$ & 534 & $376(0.312)$ & $930^{*}$ & 556 & $374(0.560)$ \\
\hline Dindigul & $407 *$ & 31 & $218(0.635)$ & $316^{*}$ & 229 & $87(0.759)$ \\
\hline Erode & $380 * *$ & 162 & $-323(0.529)$ & $283^{*}$ & 221 & $62(0.843)$ \\
\hline Kancheepuram & 126 & 449 & $x^{2}$ & 77 & 275 & $-197(0.491)$ \\
\hline Kanyakumari & 48 & . & $257(0.206)$ & 0 & . & \\
\hline Karur & $422 *$ & 165 & $-38(0.934)$ & $240^{*}$ & 202 & $38(0.809)$ \\
\hline Madurai & $529 *$ & 567 & $301(0.034) \dagger$ & $216^{* *}$ & 222 & $-6(0.988)$ \\
\hline Nagapattinam & $301 * *$ & 0 & $-80(0.771)$ & 178 & 0 & $178(0.086)^{\dagger}$ \\
\hline Namakkal & $368^{*}$ & $448^{*}$ & $-0(0.909)$ & $287^{*}$ & $292 * *$ & $-5(0.991)$ \\
\hline Nilgiris & 0 & 0 & $44(0.740)$ & 0 & 22 & $-22(0.673)$ \\
\hline Perambalur & 81 & 37 & $-269(0.411)$ & 68 & 31 & $37(0.740)$ \\
\hline Pudukottai & 63 & 332 & $-285(0.322)$ & 0 & 480 & $-480(0.094)^{\dagger}$ \\
\hline Ramanathapuram & 30 & 315 & $567(0.338)$ & 0 & 339 & $-339(0.189)$ \\
\hline Salem & $1682^{*}$ & $1115^{*}$ & $149(0.133)$ & $1342^{*}$ & $683^{*}$ & $659(0.099)^{\dagger}$ \\
\hline Sivaganga & 149 & 0 & $224(0.131)$ & $174^{* *}$ & 0 & $174(0.084)^{\dagger}$ \\
\hline Thanjavur & 224 & 0 & $150(0.295)$ & 266 & 0 & $266(0.030)^{\dagger}$ \\
\hline Theni & $150 * *$ & 0 & $319(0.597)$ & 52 & 0 & $52(0.645)$ \\
\hline Thirunelveli & $600^{*}$ & 281 & $151(0.241)$ & $326^{* *}$ & 0 & $326(0.271)$ \\
\hline Thiruvallur & 151 & 0 & $-479(0.233)$ & 55 & 0 & $55(0.077)$ \\
\hline Thiruvannamalai & 0 & 479 & $-162(0.367)$ & 0 & 496 & $-496(0.280)$ \\
\hline Thiruvarur & 0 & 162 & $0(0.059)$ & 0 & 261 & $-261(0.257)$ \\
\hline Thuthukudi & 0 & 0 & $-249(0.624)$ & 0 & 0 & $0(0.118)$ \\
\hline Tiruchirapalli & 125 & 374 & $-796(0.267)$ & 133 & $539 * *$ & $-406(0.249)$ \\
\hline Vellore & 0 & 796 & $-117(0.670)$ & 43 & 774 & $-731(0.182)$ \\
\hline Villupram & 0 & 117 & $649(0.077)^{\dagger}$ & 0 & 0 & $0(0.732)$ \\
\hline Virudhunagar & $649 *$ & 0 & & $271 *$ & 0 & $271(0.022)^{\dagger}$ \\
\hline
\end{tabular}

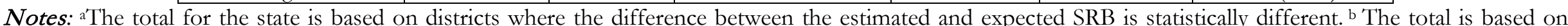
those districts where the change in deficit is statistically significant. *, ** indicate that the SRB is statistically different from the expected SRB of 952 , at the $5 \%$ and $10 \%$ level of significance, respectively. $†$ Indicates that the temporal change in SRB is statistically different from zero at at least the $10 \%$ level of significance. 
Table 5

Babies received in the Cradle Baby Scheme

\begin{tabular}{|l|c|c|}
\hline & Male & Female \\
\hline Phase 1: 1992-13.05.2001 & 0 & 150 \\
Salem & 57 & \\
\hline Phase 2: 14.05.2001-30.11.2007 & 665 \\
Salem & 30 & 109 \\
Madurai & 20 & 146 \\
Theni & 40 & 965 \\
Dharmapuri & 12 & 38 \\
Dindigul & 231 & 487 \\
Other districts & 390 & 2410 \\
Total & & \\
\hline
\end{tabular}

Source: Directorate of Social Welfare, Government of Tamil Nadu. ROC No.58544/CW6/2007, dated 3.1.2008. 
Table 6: Legal action against female infanticide, 1992 to 2003

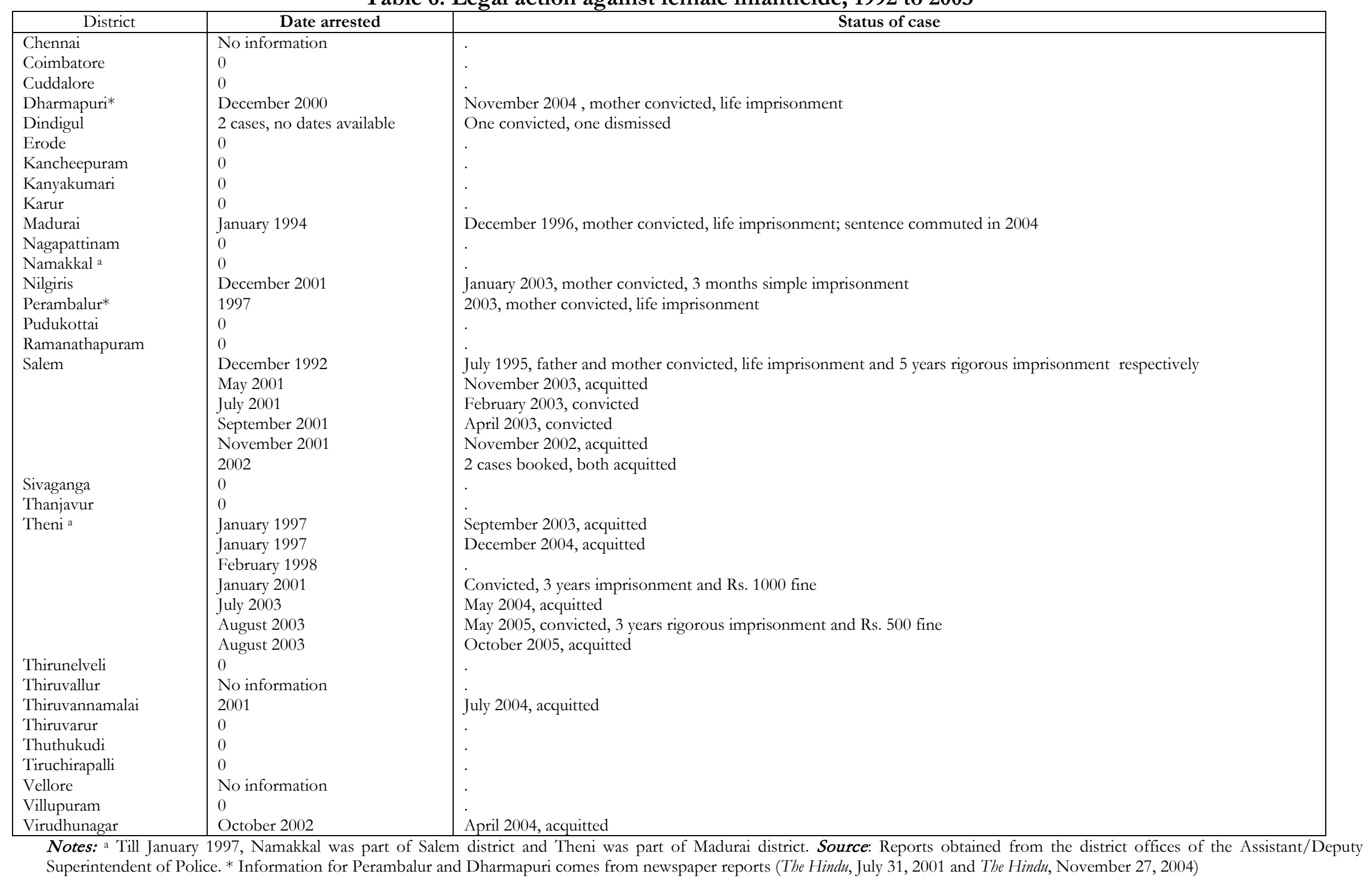


Table 7: GCPS beneficiaries and daughter deficit in Tamil Nadu

\begin{tabular}{|c|c|c|}
\hline Districts & $\begin{array}{l}\text { Distribution of } \\
\text { beneficiaries } \\
\text { (percent) } \\
2001-03 \\
\end{array}$ & $\begin{array}{l}\text { Distribution of } \\
\text { daughter deficit } \\
\text { (percent) } \\
1996-99\end{array}$ \\
\hline Chennai & 3.06 & 1.16 \\
\hline Coimbatore & 5.45 & 0.49 \\
\hline Cuddalore & 5.97 & 1.8 \\
\hline Dharmapuri & 2.83 & 18.13 \\
\hline Dindigul & 3.25 & 5.86 \\
\hline Erode & 3.76 & 4.37 \\
\hline Kancheepuram & 4.35 & 1.4 \\
\hline Kanyakumari & 5.38 & 0.71 \\
\hline Karur & 3.71 & 4.29 \\
\hline Madurai & 2.50 & 7.83 \\
\hline Nagapattinam & 3.64 & 3.22 \\
\hline Namakkal & 2.32 & 4.69 \\
\hline Nilgiris & .856 & 0.07 \\
\hline Perambalur & 1.97 & 1.24 \\
\hline Pudukottai & 2.01 & 1.2 \\
\hline Ramanathapuram & 3.54 & 0.54 \\
\hline Salem & 4.46 & 25.62 \\
\hline Sivagangai & .723 & 1.81 \\
\hline Thanjavur & 1.95 & 2.09 \\
\hline Theni & 2.67 & 3.51 \\
\hline Tirunelveli & 4.98 & 6.53 \\
\hline Tiruvarur & 1.59 & 1.85 \\
\hline Thiruvannamalai & 4.80 & 1.02 \\
\hline Thiruvallur & 4.91 & 0 \\
\hline Tiruchirapalli & 2.01 & 0.22 \\
\hline Tuticorin & 3.02 & 2.08 \\
\hline Vellore & 4.46 & 3.68 \\
\hline Virudhunagar & 2.71 & 1.05 \\
\hline Villupuram & 6.98 & 6.94 \\
\hline
\end{tabular}

Source: Directorate of Social Welfare, ROC No.58544/CW6/2007, dated 3.1.2008 
Table A1

Daughter Deficit and Interventions

Difference-in-differences estimates

\begin{tabular}{|l|c|c|}
\hline \multicolumn{1}{|c|}{ Variable } & Post-birth deficit & Pre-birth deficit \\
\hline Heavily treated*2003 & -10.71 & $-170.38^{*}$ \\
& $(16.75)$ & $(61.03)$ \\
Lightly treated*2003 & $-22.64 * *$ & -4.379 \\
& $(4.80)$ & $(17.48)$ \\
Female work participation rate & -0.407 & -8.105 \\
& $(4.221)$ & $(15.37)$ \\
Male work participation rate & 1.478 & 4.87 \\
& $(0.916)$ & $(3.33)$ \\
Male literacy & -0.997 & 4.10 \\
& $(1.824)$ & $(6.64)$ \\
Female literacy & $4.314 *$ & $-12.15+$ \\
Per capita income & $(2.135)$ & $(7.07)$ \\
& $-4.927 *$ & $20.27 *$ \\
Rainfall & $(1.943)$ & $(7.77)$ \\
& 0.0002 & -0.003 \\
Number of self-help groups & $(0.001)$ & $(0.005)$ \\
& -0.008 & 0.004 \\
Number of registered scan centers & $(0.010)$ & $(0.036)$ \\
& -0.0016 & -0.004 \\
R $N$ (within) & $(0.002)$ & $(0.006)$ \\
\hline & -0.029 & 0.165 \\
& $(0.044)$ & $(0.159)$ \\
\hline
\end{tabular}

Notes: Standard errors in parentheses; + significant at $10 \%$; significant at $5 \%$; ** significant at $1 \%$. 
Table A2

Infant Mortality Rates based on the Sample Registration System

\begin{tabular}{|c|c|c|c|c|c|c|}
\hline Year & \multicolumn{2}{|c|}{$\begin{array}{c}\text { IMR } \\
\text { Tamil Nadu }\end{array}$} & \multicolumn{2}{c|}{ IMR } & \multicolumn{2}{c|}{$\begin{array}{c}\text { IMR } \\
\text { Rural Tamil Nadu }\end{array}$} \\
\hline & Male & Female & Male & Female & Male & Female \\
\hline 1997 & 48 & 57.3 & 54.5 & 62.3 & 33.9 & 47 \\
\hline 1998 & 48.3 & 58.1 & 52.1 & 65.9 & 40 & 39.5 \\
\hline 1999 & 50.3 & 54.5 & 57.5 & 58.8 & 33.8 & 45.1 \\
\hline 2000 & 48.5 & 53.7 & 52.6 & 60.7 & 39.7 & 37.1 \\
\hline 2001 & 45 & 54 & 50 & 61 & 33 & 38 \\
\hline 2002 & 46 & 43 &. &. &. &. \\
\hline 2003 & 44 & 41 & 50 & 46 & 32 & 31 \\
\hline 2004 & 43 & 38 & 46 & 44 & 39 & 30 \\
\hline 2005 & 35 & 39 & 38 & 40 & 30 & 39 \\
\hline 2006 & 36 & 37 & 38 & 41 & 33 & 33 \\
\hline 2007 & 34 & 36 & 38 & 39 & 30 & 33 \\
\hline 2008 & 30 & 33 & 33 & 35 & 27 & 30 \\
\hline
\end{tabular}

Source: Sample Registration System, various bulletins. Office of the Registrar General, India 